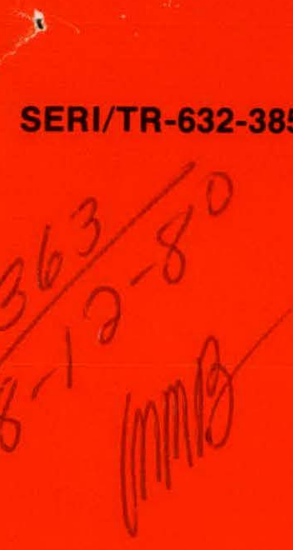

June 1980

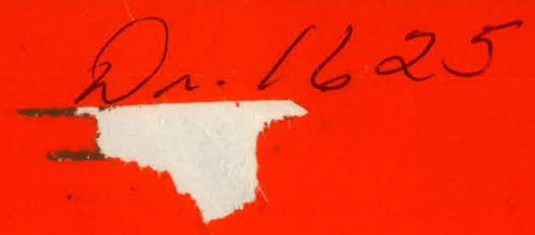

\title{
Preliminary Operational Results of the Low- Temperature Solar Industrial Process Heat Field Tests
}

Charles F. Kutscher

Roger L. Davenport
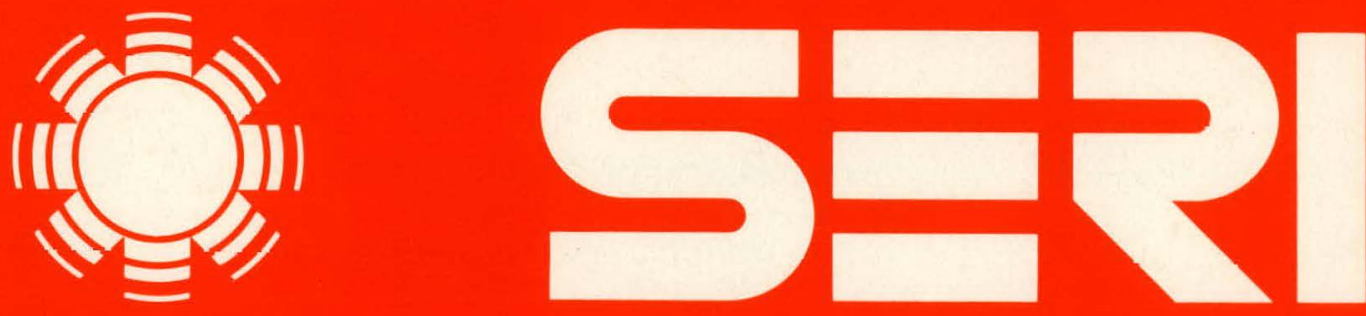

Solar Energy Research Institute A Division of Midwest Researsh Institute

1617 Cole Boulevard

Golden, Colorado 80401

Operated for the U.S. Department of Energy under Contract No. EG-77-C-01-4042 


\section{DISCLAIMER}

This report was prepared as an account of work sponsored by an agency of the United States Government. Neither the United States Government nor any agency Thereof, nor any of their employees, makes any warranty, express or implied, or assumes any legal liability or responsibility for the accuracy, completeness, or usefulness of any information, apparatus, product, or process disclosed, or represents that its use would not infringe privately owned rights. Reference herein to any specific commercial product, process, or service by trade name, trademark, manufacturer, or otherwise does not necessarily constitute or imply its endorsement, recommendation, or favoring by the United States Government or any agency thereof. The views and opinions of authors expressed herein do not necessarily state or reflect those of the United States Government or any agency thereof. 


\section{DISCLAIMER}

Portions of this document may be illegible in electronic image products. Images are produced from the best available original document. 
Printed in the United States of America Available from:

National Technical Information Service

U.S. Department of Commerce

5285 Port Royal Road

Springfield, VA 22161

Price:

Microfiche $\$ 3.00$

Printed Copy $\$ 4.50$

\section{NOTICE}

This report was prepared as an account of work sponsored by the United States Government. Neither the United States nor the United States Department of Energy, nor any of their employees, nor any of their contractors, subcontractors, or their employees, makes any warranty, express or implied, or assumes any legal liability or responsibility for the accuracy, completeness or usefulness of any information, apparatus, product or process disclosed, or represents that its use would not infringe privately owned rights. 
SERI/TR-632-385

UC CATEGORY: UC-59b

\section{MASicr}

PRELIMINARY OPERATIONAL RESULTS

OF THE LOW-TEMPERATURE SOLAR

INDUSTRIAL PROCESS HEAT FIELD

TESTS

CHARLES F. KUTSCHER

ROGER L: DAVENPORT

JUNE 1980

Prepared Under TASK No. 3472

\section{Solar Energy Research Institute}

A Division of Midwest Research Institute

1617 Cole Boulevard

Golden, Colorado 80401

Prepared for the

U.S. Department of Energy

Contract No. EG-77-C-01-4042 
THIS PAGE

\section{WAS INTENTIONALLY \\ LEFT BLANK}




\section{PREFACE}

This report presents performance results, operating experiences, and costs of the operational low-temperature industrial process heat field tests sponsored by the U.S. Department of Energy. It is hoped that the information contained in this report will contribute toward more sound and realistic design of future systems that utilize solar energy as a heat source for industrial use.

The authors would like to express their thanks to George Bush of Lawrence Livermore Laboratory who accompanied them on site visits and provided many use ful comments, particularly in the area of data acquisition.

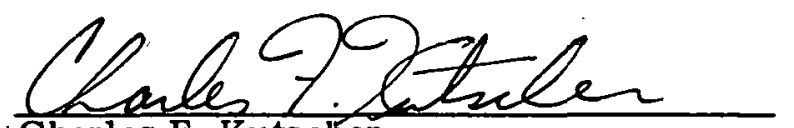

Charles F. Kutscher

Solar Thermal Engineering

Development Branch

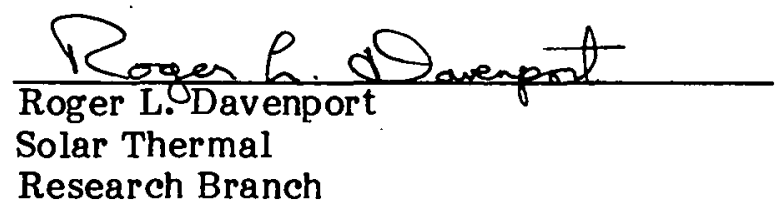

Approved for:

SOLAR ENERGY RESEARCH INSTITUTE

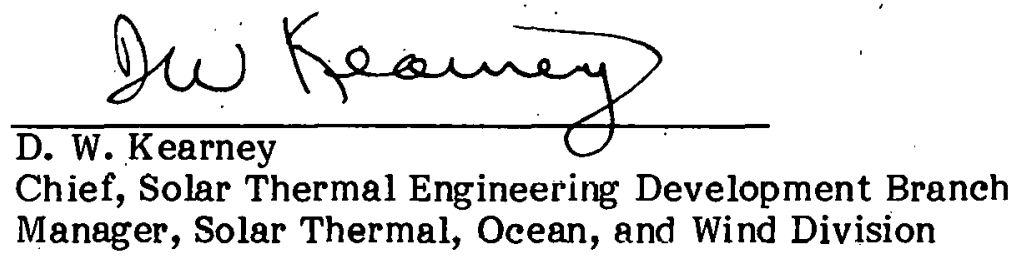




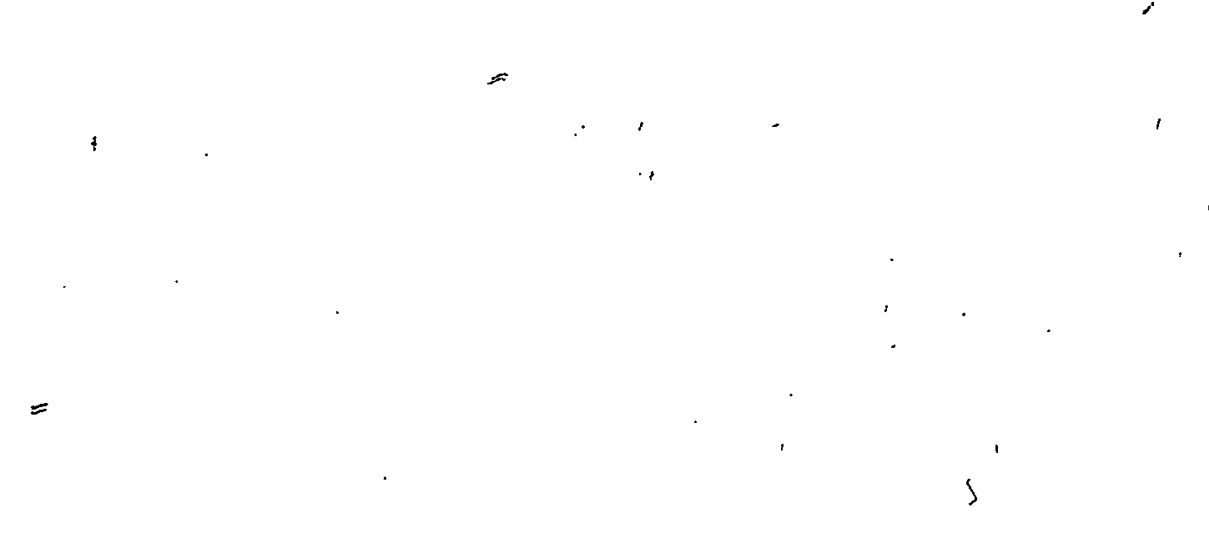

THIS PAGE WAS INTENTIONALLY

LEFT BLANK 


\section{SUMMARY}

There are currently six solar industrial process heat field tests funded by the U.S. Department of Energy (DOE) that have been in operation for one year or longer-three of these are hot water systems and three are hot air systems. All are low-temperature projects that supply process heat at temperatures below $212^{\circ} \mathrm{F}$. This report presents performance results gathered by each contractor's data acquisition system and summarizes project costs and problems encountered.

Flat-plate, evacuated-tube, and line-focus collectors are gll represented in the program, with collector array areas ranging from 2500 to $21,000 \mathrm{ft}^{2}$. Collector array efficiencies ranged from $12 \%$ to $36 \%$ with net system efficiencies from $8 \%$ to $33 \%$. Low efficiencies are attributable in some cases to high thermal losses and, for the two projects using air collectors, are due in part to high parasitic power consumption.

Problems have included industrial effluents on collectors, glazing and absorber surface failures, excessive thermal losses, freezing and overheating, and various control problems. By far, the system most prone to failure has been data acquisition; as a result, good data is scarce.

Costs of these first-gèneration systems have ranged from $\$ 71,000$ to $\$ 287,000$ for design and $\$ 286,000$ to $\$ 748,000$ for construction. Based on the total capital cost, system costs are estimated to be in the range of $\$ 39 / \mathrm{ft}^{2}$ to $\$ 142 / \mathrm{ft}^{2}$ of collector area. The costs of the systems, divided by the energy delivered by the solar systems to the processes in the first year of operation, range from $\$ 786 /(\mathrm{MBtu} / \mathrm{yr})$ to $\$ 2348 /(\mathrm{MBtu} / \mathrm{yr})$, When design and data acquisition costs are excluded, these ranges drop to $\$ 25 / \mathrm{ft}^{2}$ to $\$ 87 / \mathrm{ft}^{2}$ and $\$ 499 /(\mathrm{MBtu} / \mathrm{yr})$ to $\$ 1537 /(\mathrm{MBtu} / \mathrm{yr})$.

These projects can be characterized as successfully delivering process heat to industry, though generally at subpar performance levels due to design inadequacies or operational difficulties. As IPH field tests, they have served their purpose as a valuable learning experience for low-temperature solar industrial applications, providing important da ta in the areas of solar system design and solar/industrial process interfacing. The project contractors have estimated that these same projects, scaled up to $100,000 \mathrm{ft}^{2}$ and built in 1982 with current design knowledge, would have costs ranging from a $\$ 16 / \mathrm{ft}^{2}$ to $\$ 40 / \mathrm{ft}^{2}$ and $\$ 121 /(\mathrm{MBtu} / \mathrm{yr})$ to $\$ 292 /(\mathrm{MBtu} / \mathrm{yr})$. It remains for subsequent IPH field tests to demonstrate these expectations for improved performance and significant cost reductions. 
THIS PAGE

\section{WAS INTENTIONALLY \\ LEFT BLANK}




\section{TABLE OP CONTENTS}

$\underline{\text { Page }}$

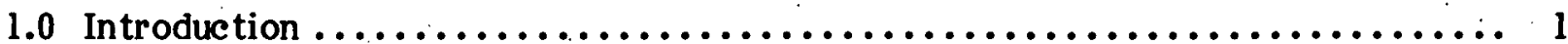

2.0 Project Descriptions and Operating Experiences $\ldots \ldots \ldots \ldots \ldots \ldots \ldots \ldots \ldots \ldots \ldots$

2.1 Campbell Soup Plant, Sacramento, Calif. ................... 5

2.2 Riegel Textile Corp., LaFrance, S.C..................... 8

2.3 York Building Products, Inc., Harr isburg, $\mathrm{Pa} . \ldots \ldots \ldots \ldots \ldots \ldots \ldots \ldots \ldots$

2.4 Gold Kist Soybean Plant, Decatur, Ala....................... 12

2.5 J. A. La Cour Kiln Services, Ine., Canton, Miss. . . . . . . . . . . . . . 13

2.6 Lamanuzzi and Pantaleo Foods, Fresno, Calif................... 15

3.0 Performance Results $\ldots \ldots \ldots \ldots \ldots \ldots \ldots \ldots \ldots \ldots \ldots \ldots \ldots \ldots \ldots \ldots \ldots \ldots \ldots$

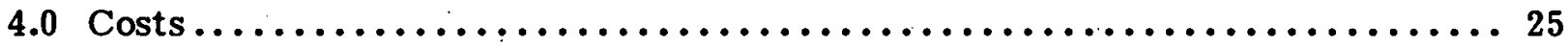

5.0 Conclusions $\ldots \ldots \ldots \ldots \ldots \ldots \ldots \ldots \ldots \ldots \ldots \ldots \ldots \ldots \ldots \ldots \ldots \ldots \ldots \ldots \ldots$

6.0 References $\ldots \ldots \ldots \ldots \ldots \ldots \ldots \ldots \ldots \ldots \ldots \ldots \ldots \ldots \ldots \ldots \ldots \ldots \ldots \ldots \ldots$ 


\section{LIST OP FIGURES}

$\underline{\text { Page }}$

2-1 Solar Water Heating System for Can Washing (Campbell Soup Plant) .......................................... 8

2-2 A Schematic of the Solar Energy System Proposed for the LaFrance Textile Mill ...................................... 9

2-3 Plumbing Schematic for Solar Heating of Rotoclave (York Building Products) $\ldots \ldots \ldots \ldots \ldots \ldots \ldots \ldots \ldots \ldots \ldots \ldots \ldots \ldots \ldots \ldots \ldots \ldots \ldots \ldots \ldots \ldots$

2-4 Schematic of Solar Drying System (Gnld Kist Soyboan Plant) _ _........ 12

2-5 Solar Kiln Heating System Schematic (J. A. LaCour) .............. 14

2-6 Schematic Solar System (L and P Foods) $\ldots \ldots \ldots \ldots \ldots \ldots \ldots \ldots \ldots$

3-1 System and Data Acquisition Availability/Utilization Graph (for the IPH Field Tests) ................................. 18

3-2 Efficiencies of the DOE-IPH Field Tests $\ldots \ldots \ldots \ldots \ldots \ldots \ldots \ldots \ldots \ldots \ldots$

\section{LIST OF TABLES}

1-1 Description Summary of Industrial Process Heat Field Test.s. . . . . . . . . . 2

1-2 Data Acquisition Systems for Industrial Process Heat Projects......... 3

2-1 Problems Encountered in DOE-Funded IPH Field Tests $\ldots \ldots \ldots \ldots \ldots \ldots$

3-1 A,B System Performance of IPH Field Tests $\ldots \ldots \ldots \ldots \ldots \ldots \ldots \ldots \ldots \ldots \ldots$

3-2 Predicted and Actual Energy Delivery of IPH Field Tests ........... 24

4-1 Costs of the Low-Temperature IPH Field Tests $\ldots \ldots \ldots \ldots \ldots \ldots \ldots \ldots$ 


\section{NOMENCLATURE}

$$
\begin{aligned}
& A_{a}=\text { Gross collector array area }\left[\mathrm{ft}^{2}\right] \text {. } \\
& c_{p}=\text { Constant-pressure specific heat of working fluid }\left[B t u / l b-{ }^{\circ} \mathrm{F}\right] \text {. } \\
& \mathrm{I}_{\mathrm{T}}=\text { Total incident solar radiation (direct plus diffuse) on collector plane during the } \\
& \dot{\mathrm{m}}=\text { Collector fluid mass flow rate }[\mathrm{lb} / \mathrm{h}] \text {. } \\
& \left.\Delta \mathrm{T}=\text { Collector outlet temperature - Collector inlet temperature }{ }^{\circ} \mathrm{F}\right] . \\
& \eta_{c}=\frac{\text { Energy Collected }}{*} \times 100 \% \\
& \eta_{\mathrm{T}}=\frac{\text { Energy Delivered* }}{\mathrm{I}_{\mathrm{T}} \mathrm{A}_{\mathrm{Q}}} \times 100 \% \\
& \eta_{\mathrm{S}}=\frac{\text { Energy Delivered* }-\xi \times \text { Parasitic Energy* }}{\mathrm{I}_{\mathrm{T}} \mathrm{A}_{\mathrm{a}}} \times 100 \% \\
& \xi=\frac{\text { Efficiency of On-Site Boiler }}{\text { Overall Central Electric Generating Plant Efficiency }}
\end{aligned}
$$

Solur System Availability** =

$$
\frac{\text { Total Period of Study - Periods of Solar System Downtime }}{\text { Total Period of Study }} \times 100 \%
$$

Solar System Utilization** =

Periods of Solar System Operation

$$
\frac{\text { Total Period of Study - Periods of Solar System Downtime }}{\text { Teriods of Solar System Operation }}
$$

*Average daily value.

**For complete definitions of these terms, see p. 20. 


\section{SECTION 1.0}

\section{INTRODUCTION}

There are currently six solar industrial process heat field tests funded by the U.S. Department of Energy (DOE) that have been in operation for one year or longer. All of these field tests are low-temperature projects supplying process heat at a temperature below $212^{\circ} \mathrm{F}$. During the 1979 calendar year, personnel from the Solar Energy Research Institute (SERI) visited all of these field tests as well as their respective contractors in order to obtain performance and cost data and details of project experiences. The six sites visited include three hot water and three hot air systems, and Table 1-1 lists their major characteristics. This report summarizes and analyzes the cost and performance of each of these projects and discusses the operational problems encountered at each site.

Performance of the field tests has been analyzed in terms of the availability and utilization of the solar energy systems, collector and system efficiencies, and parasitic power consumption. Actual costs and estimated construction costs have been reduced to dollars per square foot of collector and dollars per annual million Btu delivered by the system for comparison.

In each project the contractor designed his own data acquisition system, and a summary of the systems is given in Table 1-2. Because different data acquisition systems were used for these projects, the type of data recorded and its quality have varied considerably from one site to another. The available performance da'ta has been compiled in tables to facilitate comparison. However, certain gaps exist in these tables. In particular, little data is available for the Campbell Soup plant. Collector array efficiency has been measured for only a few months, and system efficiency is not known. Also, the Riegel Textile plant has reduced data for only three days of operation, although raw data was collected for a much longer period.

In essence, then, this report reflects SERI's best effort at performance and cost analysis given limited information. Better analysis can only be supported by better data. In order to avoid such problems in the future, SERI has written a set of Data Acquisition and Analysis Guidelines to be used by current DOE contractors. Ultimately, it is intended that a uniform data acquisition hardware system be chosen and used in future solar industrial process heat field tests. 
Table 1-1. DESCRIPTION SUMMARY OF INDUSTRIAL PROCESS HEAT FIELD TESTS

\begin{tabular}{|c|c|c|c|c|c|c|c|c|}
\hline Project Location & Contraetor & Applicetion & Type of Collector & $\begin{array}{l}\text { Collector } \\
\text { Fluid }\end{array}$ & $\begin{array}{l}\text { Collection } \\
\text { Temp. } \\
\text { (F) }\end{array}$ & $\begin{array}{l}\text { Process } \\
\text { Temp. } \\
(\rho \mathrm{F})\end{array}$ & $\begin{array}{l}\text { Area } \\
\left(\mathrm{ft}^{2}\right)\end{array}$ & $\begin{array}{l}\text { Thermal } \\
\text { Storage }\end{array}$ \\
\hline \multicolumn{9}{|l|}{ Hot Water Projects } \\
\hline $\begin{array}{l}\text { Campbell Soup Company } \\
\text { Sacramento, Calif. }\end{array}$ & $\begin{array}{l}\text { Acure: Corp: } \\
\text { Mountain View, Calif. }\end{array}$ & $\begin{array}{l}\text { Can } \\
\text { veshing }\end{array}$ & $\begin{array}{l}\text { Solargenics } 77 \text { Series } \\
\text { Flat plate and A curex } \\
\text { Model } 3001-1 \\
\text { E-W parabolic trough }\end{array}$ & Water & 150 & $180-195$ & 7335 & $\begin{array}{l}19,000 \mathrm{gal} . \\
\text { hot water }\end{array}$ \\
\hline $\begin{array}{l}\text { Riegel Textile Corp. } \\
\text { LaFrance, S.C. }\end{array}$ & $\begin{array}{l}\text { General Elestric Co. } \\
\text { Philadelphic, P.a. }\end{array}$ & $\begin{array}{l}\text { Textile } \\
\text { dyeing }\end{array}$ & $\begin{array}{c}\text { GE TC-100 } \\
\text { Evacuated tube }\end{array}$ & $\begin{array}{l}\text { Water/ethylene } \\
\text { glycol }\end{array}$ & 270 & 190 & 6680 & $\begin{array}{l}8,000 \text { gal. } \\
\text { hot water }\end{array}$ \\
\hline $\begin{array}{l}\text { York Building Products, Inc. } \\
\text { Harrisburg, Pa. }\end{array}$ & $\begin{array}{l}\text { AAI Corp. } \\
\text { Baltimore, N-d. }\end{array}$ & $\begin{array}{l}\text { Conerete } \\
\text { block curing }\end{array}$ & $\begin{array}{l}\text { AAI } 24: 1 \\
\text { Multiple reflector } \\
\text { linear concentrator }\end{array}$ & $\begin{array}{l}\text { Water/ethydene } \\
\text { glycol }\end{array}$ & 135 & $135-180$ & 9216 & $\begin{array}{l}50,000 \mathrm{gal}^{8} \\
\text { hot water }\end{array}$ \\
\hline \multicolumn{9}{|l|}{ Hot Air Projects } \\
\hline $\begin{array}{l}\text { Gold Kist, Inc. } \\
\text { Decatur, Ala. }\end{array}$ & $\begin{array}{l}\text { Teledvne-Brown Engr. } \\
\text { Huntsille, A.la. }\end{array}$ & $\begin{array}{l}\text { Soybean } \\
\text { trying }\end{array}$ & $\begin{array}{l}\text { Solaron Series } 2000 \\
\text { flat plate }\end{array}$ & Air & 140 & $155-175$ & 13104 & None \\
\hline $\begin{array}{l}\text { J.A. LaCour Kiln Services, } \\
\text { Inc. } \\
\text { Canton, Miss. }\end{array}$ & $\begin{array}{l}\text { Lockhzed Vissiles and Space Co. } \\
\text { Huntszille, fila. }\end{array}$ & $\begin{array}{l}\text { Lumber } \\
\text { trying }\end{array}$ & $\begin{array}{l}\text { Chamberlain Model } 11301 \\
\text { flat plate }\end{array}$ & Water & 142 & $110-160$ & 2520 & $\begin{array}{l}5,000 \text { gal. } \\
\text { hot water }\end{array}$ \\
\hline $\begin{array}{l}\text { Lamanuzzi and Pantaleo Fcoods } \\
\text { Fresno, Celif. }\end{array}$ & $\begin{array}{l}\text { California PJlytechnic State U. } \\
\text { Sen Luis Ot:spo, Calif. }\end{array}$ & $\begin{array}{l}\text { Fruit } \\
\text { drying }\end{array}$ & $\begin{array}{l}\text { Site fabricated } \\
\text { flat plate }\end{array}$ & Air & 145 & $140-150$ & 21000 & $\begin{array}{l}14,000 \mathrm{ft}^{3} \\
\text { rock bin }\end{array}$ \\
\hline
\end{tabular}


Table 1-2. DATA ACQUISITION SYSTEMS FOR INDUSTRIAL PROCESS HEAT PROJECTS

\begin{tabular}{|c|c|c|c|}
\hline Projeet & On-Site Equipment & Reduction Procedure & Remarks \\
\hline Campbell Soup & $\begin{array}{l}\text { Acurex Autodata Nine } \\
\text { data logger, magnetic } \\
\text { tape recoriter, line } \\
\text { printer }\end{array}$ & $\begin{array}{l}\text { Magnetic tape picked up } \\
\text { by contractor; reduced } \\
\text { by computer at contractor's } \\
\text { offices }\end{array}$ & $\begin{array}{l}\text { Due to failure of flow meter } \\
\text { and magnetic tape, no data } \\
\text { computer-processed yet. }\end{array}$ \\
\hline Riegel Textile & $\begin{array}{l}\text { Esterline-Angus data } \\
\text { logger, majnetic tape } \\
\text { recorder }\end{array}$ & $\begin{array}{l}\text { Magnetic tape mailed to } \\
\text { contractor; reduced on } \\
\text { PDP-11 at contractor's } \\
\text { offices }\end{array}$ & $\begin{array}{l}\text { Much raw data taken, } \\
\text { but very little has been } \\
\text { reduced. }\end{array}$ \\
\hline York Building Products & $\begin{array}{l}\text { Fluke } 2240 \text { B data } \\
\text { logger, magnetic tape } \\
\text { recorder }\end{array}$ & $\begin{array}{l}\text { Magnetic tapes picked } \\
\text { up by contractor and } \\
\text { reduced by computer } \\
\text { at contrac tor's of fices }\end{array}$ & $\begin{array}{l}\text { Earlier data logger (different brand) } \\
\text { had failed and was replaced. Some } \\
\text { errors in tape for matting have caused } \\
\text { problems. }\end{array}$ \\
\hline Gold Kiṣt & $\begin{array}{l}\text { Fluke } 2240 \text { B data } \\
\text { logger }\end{array}$ & $\begin{array}{l}\text { Paper tape picked up by } \\
\text { contractor; data manually } \\
\text { keypunched and reduced by } \\
\text { computer at contractor's } \\
\text { offices }\end{array}$ & $\begin{array}{l}\text { Data logger da maged when } \\
\text { hea ter failed in subf reezing } \\
\text { temperatures, but quickly } \\
\text { repaired. }\end{array}$ \\
\hline LaCour Kiln Services & $\begin{array}{l}\text { PDP-11/03 minicomputer, } \\
\text { disc drive, line printer }\end{array}$ & $\begin{array}{l}\text { Data automatically reduced } \\
\text { un site; printout mailed } \\
\text { to contractor's office }\end{array}$ & $\begin{array}{l}\text { Pipe failure sprayed water and } \\
\text { steam on system. Repaired for } \\
\$ 3,000 \text {. Recently damaged by } \\
\text { a flood. }\end{array}$ \\
\hline$L$ and P Foods & $\begin{array}{l}\text { Acurex Autodata Nine } \\
\text { data logger, cassette } \\
\text { recorder }\end{array}$ & $\begin{array}{l}\text { Da ta read once per day } \\
\text { from cassette tape; transmitted } \\
\text { via commercial telephone line } \\
\text { to contractor's office where } \\
\text { it is reduced by an HP- } 9825 \\
\text { desk top calcula tor }\end{array}$ & $\begin{array}{l}\text { Some problems interfacing with telephone } \\
\text { company and obtaining proper } \\
\text { transmission equipment. }\end{array}$ \\
\hline
\end{tabular}




\section{SERI}




\section{SECTION 2.0}

\section{PROJECT DESCRIPTIONS AND OPERATING EXPERIENCES}

A summary description of the six projects is given in Table 1-1. In this section, each process is described and problems encountered are discussed. A brief description of the attitude of plant personnel is also given. A summary of the problems encountered at each site and corrective actions taken is given in Table 2-1. More details concerning the design of each of the six projects can be found in Ref. 1.

\subsection{CAMPBELI SOUP PLANT, SACRAMENTO, CALIP.}

The first of the six projects to become operational was the solar water-heating system installed by the Acurex Corp. at Campbell Soup's production facility in Sacramento, Calif. In this system, solar-heated water at a flow rate of approximately $12.5 \mathrm{gpm}$ is supplied directly to a can-washing line (see Fig. 2-1). The south-facing collector array, mounted atop a warehouse roof, consists of $4455 \mathrm{ft}^{2}$ of Solargenics flat-plate collectors (models 77-16.5/LI/CL and 77-11,5/LI/CL, single-glazed with a flat black absorber coating) inclined at $25^{\circ}$ and $2880 \mathrm{ft}^{2}$ of Acurex (model $3001-1$ ) parabolic troughs mounted with their axes east-west. Potable water is supplied from a well, preheated in the flat plates, and then heated to temperatures as high as $195^{\circ} \mathrm{F}$ in the troughs. A 19,000 -gal insulated steel storage tank is used to store hot water over the weekend. A steam heat exchanger is used to boost water temperature to $195^{\circ}$ when solar energy is insufficient. The system was designed to supply all of the hot water needs to one of the 20 parallel washing lines on a peak June day, or $74 \%$ of a single line's energy needs on an annual basis.

One of the first problems encountered in this project was an unexpected shutdown of the solar can-washing line. As a result of changing consumer demand, it was decided to switch the line over to a different type of soup. Since the solar-heated water was dedicated to this particular line instead of being supplied centrally, the solar system sat idle for the several weeks while the can line was shut down for the changeover.

Some condensation has occurred on the inner surface of the glazing on a number of the flat-plate collectors, though otherwise they are apparently in good condition. The parabolic troughs have not fared as well, however. A large number of the glass tubes that cover the absorber pipe have broken, probably due to inadequate clearance for thermal expansion/contraction. In the spring of 1978 they were also damaged in a storm with winds of up to $80 \mathrm{mph}$.

The majpr pmhlems with this installation have been the control and measurement of flow through the collectors. The digital flow valve originally installed did not function properly dise to line pressure surges and was replaced with a Kates flow control valve that varies flow according to the time of day. The original flowmeters failed and were never replaced. In addition, the data logger and magnetic tape recorder failed due to excessive heat in the sun-lit stairwell in which they are located. An exhaust fan was installed to cool the data logger, but the magnetic tape recorder was not replaced until late in 1979. As a result of these problems, little reliable data has been obtained from this project. 
Table 2-1. PROBLEMS ENCOUNTERED IN DOE-FUNDED IPH FIELD TESTS

\begin{tabular}{|c|c|c|}
\hline Project & Problems & Zorrective Action \\
\hline Campbell Soup & $\begin{array}{l}\text { Data logger failure } \\
\text { Magnetic tape reco:der failure } \\
\text { Nonoperative flow meter } \\
\text { Broken glass cover tubes } \\
\text { Wind damage } \\
\text { Stutdown of can line while } \\
\text { changing soup type }\end{array}$ & $\begin{array}{l}\text { Exhaust fan installed } \\
\text { None } \\
\text { Replaced with kates control valve, } \\
\text { as yet uncalibrated } \\
\text { Will be replaced } \\
\text { Repaired damage } \\
\text { None }\end{array}$ \\
\hline Riegel Textile & $\begin{array}{l}\text { Contamination of reflectors } \\
\text { ty boiler stack } \in \text { ffluents } \\
\text { Excessive night lcsses } \\
\text { Trermal shock tube breakage } \\
\text { Lcw flow rate through collector } \\
\text { Pcor insulation in collector } \\
\text { headers }\end{array}$ & $\begin{array}{l}\text { None, effect is being studied } \\
\text { Replace supply gipe with smaller- } \\
\text { diameter pipe :o reduce thermal mass } \\
\text { Installed over-temperature indicator; } \\
\text { circuit box mode less accessible } \\
\text { Will install larger manifold fittings and } \\
\text { will increase impeller diameter of pump } \\
\text { Will replace leaky grommets and add more } \\
\text { insulation }\end{array}$ \\
\hline York Building Products & $\begin{array}{l}\text { Failure of black chrome coating } \\
\text { Thermosiphon freezeup } \\
\text { Mirror breakage (thermal) } \\
\text { Insufficient wire size for motors } \\
\text { Drive motor grease too thick } \\
\text { Data logger not compatible } \\
\text { with tape drive } \\
\text { Mirror desilvering } \\
\text { Dust problems with data logger }\end{array}$ & $\begin{array}{l}\text { Painted rusted Eneas with flat black } \\
\text { paint } \\
\text { Installed check ualves in collector } \\
\text { loop piping; replaced heat exchanger tube } \\
\text { bundle } \\
\text { Mirrors will be replaced } \\
\text { Replaced wires with heavier gauge } \\
\text { Replaced grease with low-temperature grease } \\
\text { Replaced data logger with different } \\
\text { brand } \\
\text { None; effect is being studied to } \\
\text { determine necessary number of coats of } \\
\text { epoxy to mirror becks } \\
\text { Relocated to buüding lobby }\end{array}$ \\
\hline
\end{tabular}

\section{Data logger failure \\ Magnetic tape reco:der failure}

Broken glass cover tubes

Wind damage

Srutdown of can line while

changing soup type

Contamination of reflectors

ty boiler stack $\in$ ffluents

(csses

Pcor insulation in collector
headers

Failure of black chrome coating

Thermosiphon freezeup

Mirror breakage (thermal)

Insufficient wire size for mators

Date loger not campatible

with tape drive

Dust problems with data logger
Exhaust fan installed

None

as yet uncalibrated

Repaired damage

None

diameter pipe $: 0$ reduce thermal mass

Installed over-temperature indicator;

circuit box merde less accessible

install laroer manifold fittings and

will replace leaky grommets and add more insulation

Painted rusted \&.eas with flat black paint

anger tube

Replaced data logger with different

brand

epoxy to mirror becks

Relocated to bauiding lobby 
Table 2-1. PROBLEMS ENCOUNTERED IN DOE-PUNDED IPH FIELD TESTS (concluded)

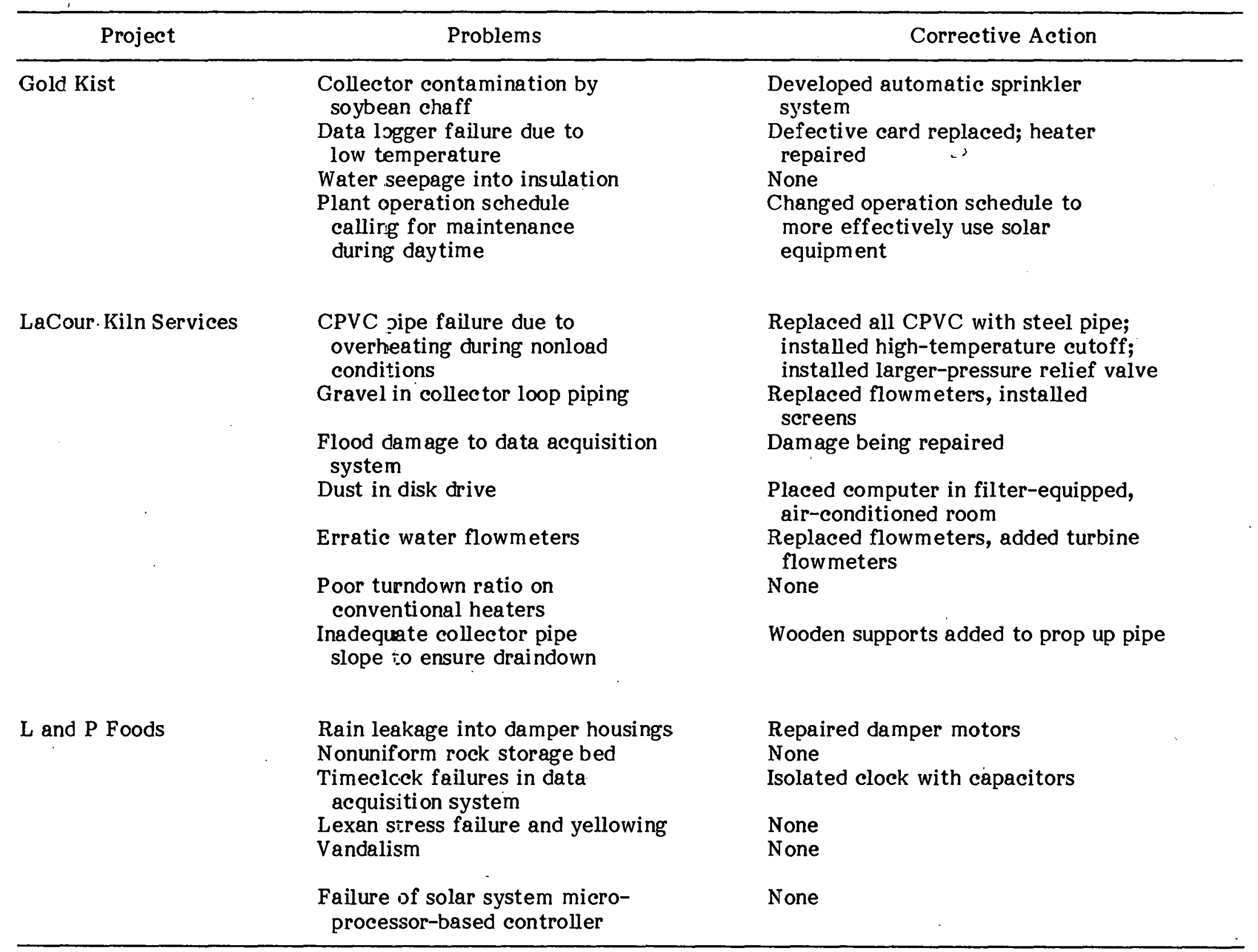

\author{
soybean chaff \\ Data logger failure due to \\ wemperature \\ Plant operation schedule \\ callirg for maintenance \\ during daytime
}

CPVC sipe failure due to overheating during nonload conditions

piping

age to date acquisition system

Erratic water flowmeters

Poor turndown ratio on adequate collector pipe

Rain leakage into damper housings Nonuniform rock storage bed

Lexan siress failure and yellowing

processor-based controller
Developed automatic sprinkler

repaired $\quad$

None

Chonged operation schedule to more effectively use solar equipment

eplaced all CPVC with steel pipe; installed high-temperature cutoff installed larger-pressure relief valve installed screens

Placed computer in filter-equipped, air-conditioned room

inged turbine

flowmeters

Wooden supports added to prop up pipe

motors

None

None

None 


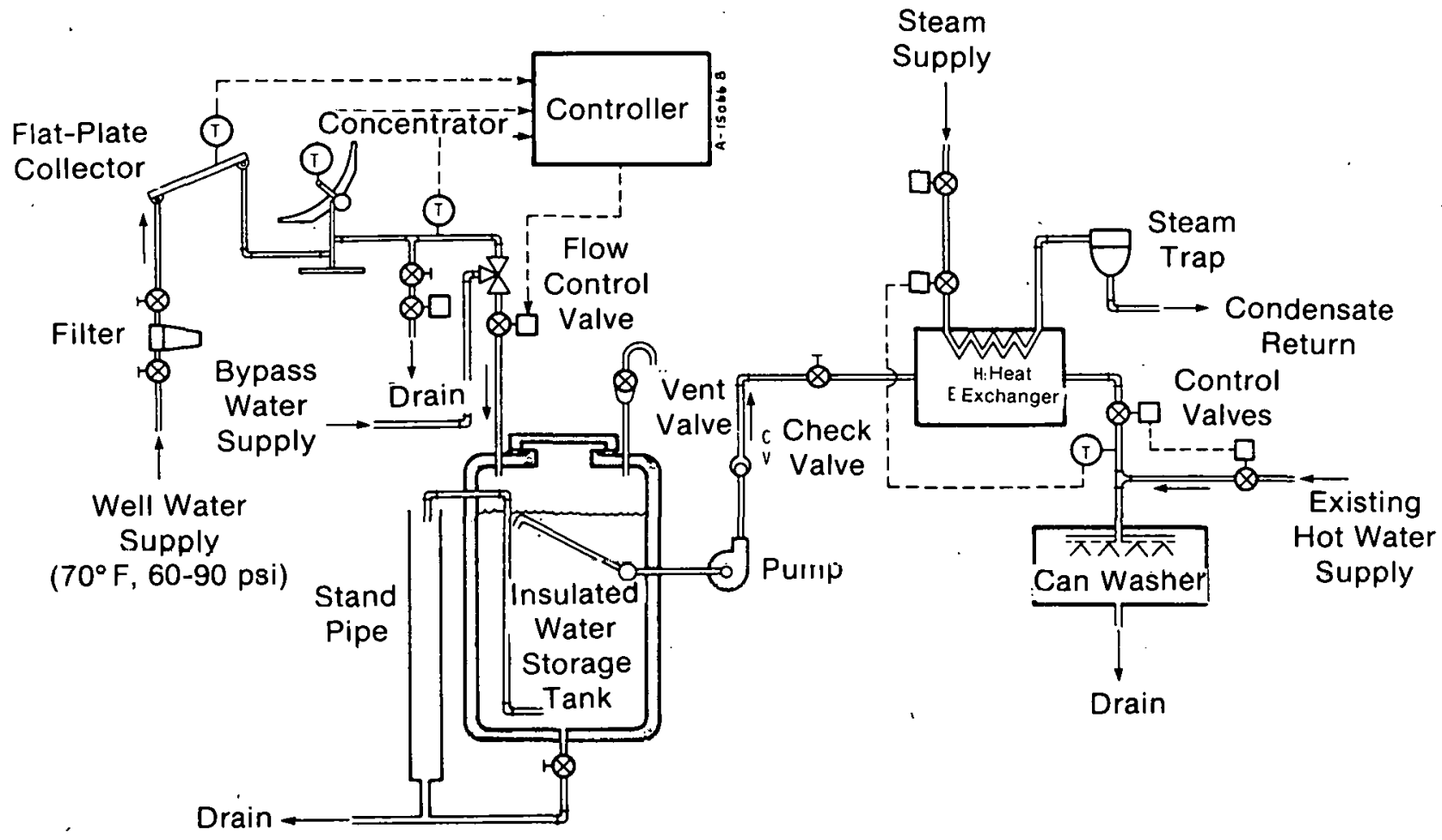

Figure 2-1. Solar. Water Heating System for Can Washing (Campbell Soup Plant)

An effort will be undertaken by the contractor to correct many of the problems that have occurred at the site, including the replacement of broken glass receiver tubes, calibration of the Kates control valve and its connection to the data logger to provide flow indications, installation of a flow regulator in the can lines, and replacement of the magnetic tape recorder. In addition, a data reduction procedure will be set up to ensure that raw data is reduced on a biweekly basis.

The personnel at the Campbell Soup plant are generally interested in the solar system but want to know how much gas the system has saved them. Because of the problems with the dnta aequisition system, they have not been able to obtain this information. Also, plant personnel are accustomed to the simple analog controllers used throughout most of the plant and are somewhat uncomfortable with the solid state controls on the solar system and the da ta logger.

\subsection{RIEGEL TEXTILE CORP., LQFRANCE, S.C.}

The application of solar energy to the dyeing of fabrics is demonstrated at the Riegel Textile Plant in LaFrance, S.C., in a hot-water system designed and built by the General Electric Co. In this plant, a pressurized water/ethylene glycol mixture flows through 
evacuated tube collectors at $76 \mathrm{gpm}$, and the collected heat is transferred via two heat exchangers first to storage and then to a dye beck (see Fig. 2-2). (A dye beck is a tank in which batches of fabrics are dyed by soaking in a hot solution of dye and water.) The ground-mounted collector array for the solar system consists of $6680 \mathrm{ft}^{2}$ of GE TC-100 collector panels that can heat the water/ethylene glycol mixture to $270^{\circ} \mathrm{F}$. An 8000 -gal storage tank is used to store heat when the dye beck is not operating. The system was designed to supply $80 \%$ of the energy required by one of the dye becks during the spring and summer and as much as $50 \%$ in the winter.

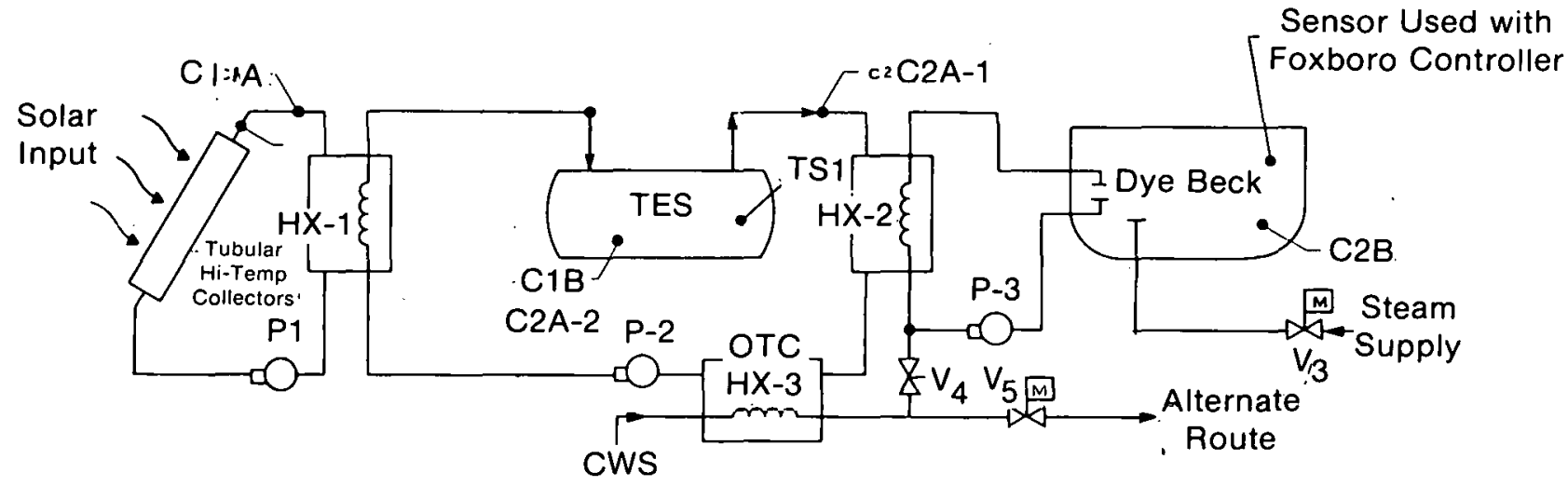

Figure 2-2. A Schematic of the Solar Energy System Proposed for the LaFrance Textile Mill

Several problems have caused energy collection to be less than predicted. Nighttime thermal losses from fluid in the collector loop have been high, resulting in an estimated $10 \%$ decrease in daily performance. The possibility of a drain-down system, where the collector loop would be emptied each night, was rejected because of the potential of trapping air in the collectors during refill. Replacing the $1000 \mathrm{ft}$ of 3 -in. diameter feeder pipe with 2-1/2 in. pipe to reduce the thermal mass of the collector loop was considered; however, this would increase required circulation pumping power considerably. Because the system pressure head loss was underestimated in design, the flow rate supplied by the pump has been approximately $0.19 \mathrm{gpm}$ per collector panel instead of the optimal $0.25 \mathrm{gpm}$. This has decreased collector efficiency by perhaps as much as $5 \%$. Additionally, the collector headers were not properly insulated, resulting in thermal "short circuits" to the collector frame. This problem has been aggravated by leaky collector grommets that have allowed insulation to get wet.

Glass breakage has been a problem with the collector array. Approximately $1 \%$ of the glass tubes broke during installation. Another 3\% broke when the collectors were thermally shocked due to being filled with cold water when they were too hot from a stagnation condition. The stagnation situation occurred when someone shut off the circuit breaker that controlled the circulation pump for the collectors. A temperature indicator has since been added to prevent the collectors from being filled when they are overheated, and the circuit breakers have been relocated to a less visible area.

Loss of collector fluid was a problem at the beginning of operation. Many collector panel fittings were overtightened on installation, resulting in leaks. Over the first few months 
of operation, the defective fittings were found and replaced and no further problems have been encountered.

Since the collectors are located downwind of a boiler, stack emissions have decreased the reflectivity of the aluminum reflectors used behind the evacuated tubes. Testing is now being performed to determine the effect on collector efficiency.

A program will soon begin to correct the existing problems. Collector grommets and insulation will be replaced with improved versions to decrease thermal losses. To increase collector flow rate, 3/4-in. tee fittings at the collectors will be replaced by 1 -in. fittings, and a larger (5-in.) impeller will be installed in the primary collector-loop pump. Reflectors will be washed, and the resulting change in system performance will be measured.

The Riegel plant is currently switching much of its dyeing process over to continuous Kuster dye becks that can process much more fabric than the existing batch units. However, batch-type dye becks are still widely used in the industry, and the results of the present solar-heated batch process can still be valuable. The plant management is generally pleased with the solar system and realizes that although it supplies a very small fraction of the plant's energy, it is just a first step.

\subsection{YORK BUILDING PRODUCTS, INC., HARRISBURG, PA.}

This project was designed and built by the AAI Corp. to heat water for the curing of concrete blocks at the York Building Products, Inc. plant in Harrisburg, $\mathrm{Pa}$. The project is unique in that the solar energy system was included in the new plant design (see Fig. 2-3). A water/ethylene glycol mixture is solar-heated at a flow rate of $425 \mathrm{gpm}$ and supplies heat through a heat exchanger to the water in a large, underground "rotoclave" in which concrete blocks are cured. 'The collector array is an integral part of a roof structure under which cured concrete blocks are stored. It consists of $9216 \mathrm{ft}^{2}$ of AAI 24:1 multiple-reflector linear concentrators that heat the water/ethylene glycol mixture to temperatures as high as $210^{\circ} \mathrm{F}$. The donut-shaped rotoclave, $180 \mathrm{ft}$ in diameter, contains about 50,000 gal of water and serves as built-in storage. Stacks of concrete blocks are put in a steel "boat" floating in the hot water, and the boat rotates, making a complete circuit around the rotoclave in 12 hours. The solar system was designed to supply over $30 \%$ of the energy required by the rotoclave.

The most visible problem with this project has been deterioration of the black chrome selective surface on the absorber pipes. No glass cover is used, and thus the absorber surface is exposed to the elements. Heavy rust could be seen in muny places. It is believed that either the nickel substrate was of insufficient thickness or the selective surface was otherwise improperly applied. In some places, an effort was made to cover the deteriorated surfaces with flat black paint. However, the surface was not prepared properly, and this paint is peeling.

Each reflector blade in the collector consists of two segments of glass mirror. When these were attached to the aluminum backing, no gaps were left to allow for differential expansion/contraction between the glass and aluminum. As a result, a number of the mirrors have visible cracks. The design has since been altered to avoid this problem. Another problem has been the desilvering of some of the mirrors. This effect is being studied in order to determine the number of layers of epoxy necessary to provide adequate protection to the mirror edges. 


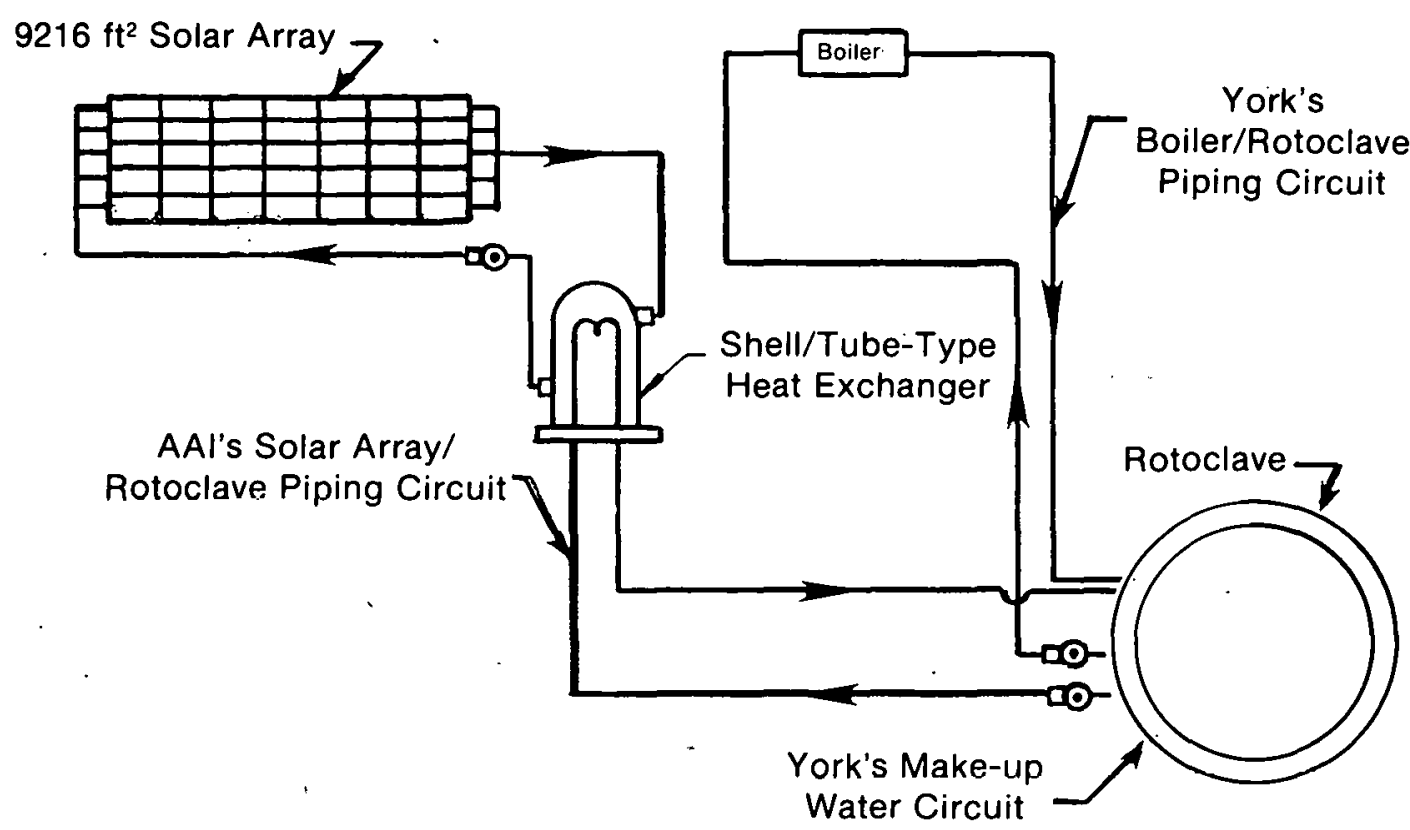

Figure 2-3. Plumbing Schematic for Solar Heating of Rotoclave (York Building Products)

On 13 January 1979, approximately four months after system dedication, the outdoor temperature fell to $-10^{\circ} \mathrm{F}$, and natural convection in the collector loop set up a reverse thermosiphon (natural convection) flow. This reverse thermosiphon loop cooled the antifreeze mixture in the collector loop below $32^{\circ} \mathrm{F}$, which caused the water in the heat exchanger to freeze and burst tubes. The tube bundle was replaced, check valves were installed to correct the original design inadequacy, and the system was operating again on 28 February. Bypass lines were installed around the check valves to decrease system pumping head during summer operation. However, the check valve flow resistance proved to be low, and the bypass lines are not used.

Un one occasion the collector loop overheated, causing a loss of coolant through the pressure relief valve. This is believed to have been caused by a power line surge that shut down power to the circulation pump and did not permit the collectors to defocus. Unfortunately, the data acquisition system was not operating at the time. Evidently, no da mage resulted.

There were numerous data acquisition problems in the early months of operation. The control console, which was originally located in the block-processing area, had to be moved to the front office because of dust and dirt problems. However, this relocation also resulted in a fortuitous increase in visibility of the project for the public. The original data logger could not be made compatible with the magnetic tape recorder and, after approximately five months, was replaced with a different brand. However, some formatting problems with the raw data tape have occurred since, rendering some of the raw da ta nonreducible. 
There were some minor problems involving the mechanical tracking mechanism of the collectors. Drive motor grease became too thick in cold weather and was replaced with a low-temperature type. Also, the drive motor wires proved to be too thin for the long run leng ths and were replaced with a heavier gauge.

The plant management at York is very concerned with fuel availability. This solar energy system can potentially supply a sizable fraction of the plant's total energy needs; therefore, plant management is quite interested in its operation.

\subsection{GOLD KIST SOYBBEAN PLANT, DECATUR, ALA.}

With the cooperation of Gold Kist, Inc., Teledyne-Brown Engineering has designed and built this solar system to supply preheated alr to a grain-drying plant in Decatur, Ala. This solar system preheats ambient air at a flow rate of $27,000 \mathrm{ft}^{3} / \mathrm{min}$ and supplies it along with ambient combustion air to a dryer house (see Fig. 2-4). The dryel house has three oil-fired furnaces (each requiring $150,000 \mathrm{ft}^{3} /$ min of combustion air) capable of drying. 3000 bushels of soybeans per hour. The collector array consists of $13,104 \mathrm{ft}^{2}$ of Solaron series 2000 air (flat-plate) collectors suppor ted above ground at a tilt of $15^{n}$ by a massive steel I-beam structure. (The expensive above-ground structure was built to permit the space below to be used for parking, but this has not materialized.) The collectors heat the air to approximately $140^{\circ} \mathrm{F}$, and it is then carried by a $150-\mathrm{ft}$ long, $4-\mathrm{ft}$ by $4-\mathrm{ft}$ insulated duct to the dryer house.

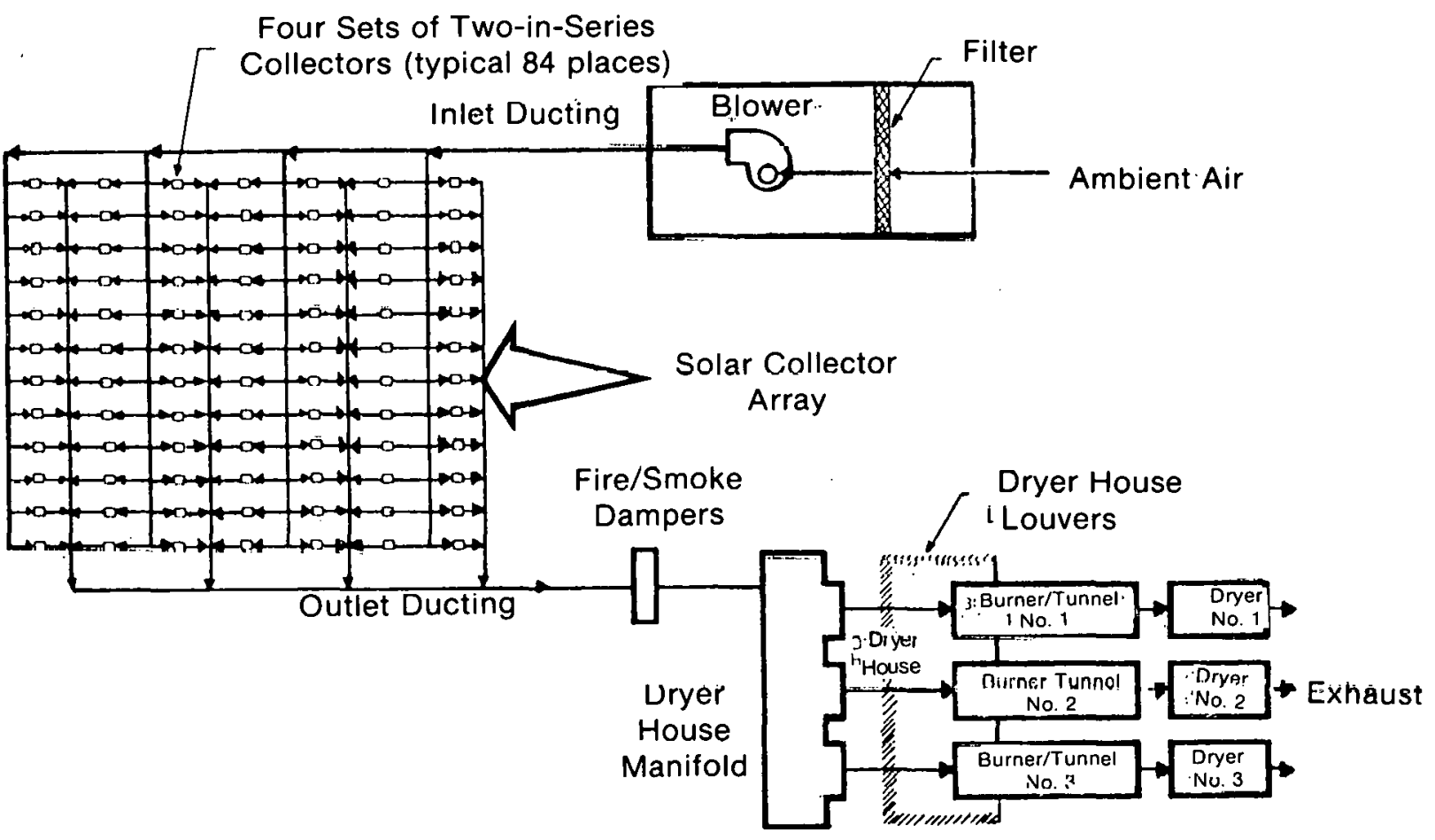

Figure 2-4. Schematic of Solar Drying System (Gold Kist Soybean Plant) 
The most frustrating problem at this site has been collection of soybean chaff and oil on the collector glazings. This residue evidently polymerizes into a gummy substance that is difficult to remove. A program of manually cleaning the collectors approximately every forty days has indicated that the dirty collectors can have an efficiency of three or more percentage points lower than clean ones. A daily, automated washing system has since been instituted that can evidently keep a panel in fairly clean condition. A flow rate 15\% lower than the design value (possibly due to fan belt slippage) has resulted in a further reduction in collector efficiency due to higher average temperatures in the collectors and ducts.

A rather surprising but serious problem was caused by plant operating practices. Maintenance on the dryers is performed for about six hours every two days, during which time the dryers are shut off. After collector installation, this maintenance continued to be performed during the day. (Possible reasons were a preference of the most experienced personnel to work the day shift and lower labor costs during the day.) Since there is no storage in the solar system, no energy could be collected during these maintenance periods. This situation continued for several months, but has now been adjusted.

Although the data acquisition system has been fairly reliable, the data logger failed one night when the outdoor air temperature dropped to $8^{\circ} \mathrm{F}$ and the heaters in the shed housing the data acquisition system failed. A damaged card from the data logger was sent to the manufacturer and a new one arrived in only four days. Only about one week of data was lost as a result of the damage.

Water has seeped into duct insulation in several places and, in some cases, has caused the insulation to sag. Temperature readings at the inlet and outlet of the duct to the dryer house have not been of sufficient accuracy to determine the amount of heat loss from the duct.

The energy contribution from the solar system has been too small to expect a great deal of interest on the part of the plant owners. Indications are, however, that Gold Kist enjoys displaying the system to the public.

\subsection{J. A. LaCOUR KILN SERVICES, RNC., CANTON, MISS.}

The application of solar energy to the kiln drying of lumber is demonstrated at the LuCour Klln in Canton, Miss., with a solar system designed and built by Lockheed Missiles and Space Co. Although considered a hot air project, this system circula tes hot water in the collector loop and supplies it to water/air heat exchanger tubes in two hardwood lumber drying kilns (see Fig. 2-5). The collector array, mounted on the roof of a lumber storage building, consists of $2520 \mathrm{ft}^{2}$ of Chamberlain model 11301 doubleglazed, flat-plate collectors with black chrome selective coatings. The sawtooth array includes $2400 \mathrm{ft}^{2}$ of aluminum reflectors that are believed to enhance annual collection by $25 \%$. A 5000 -gal insulated steel storage tank is included in the loop, and freeze protection is provided by draining down the collector water into the tank. The system was designed to supply $22 \%$ of the energy needs of two kilns.

A serious problem occurred soon after the system became operational. During a period of low heat usage, the storage tank overheated, causing failure of the CPVC (chlorinated polyvinyl chloride) pipe connecting the storage tank to the collectors. This caused a serious leak inside the storage tank shed that also houses the data acquisition system. The PDP-1l computer was sprayed with hot water and steam, and recurring breakdowns 


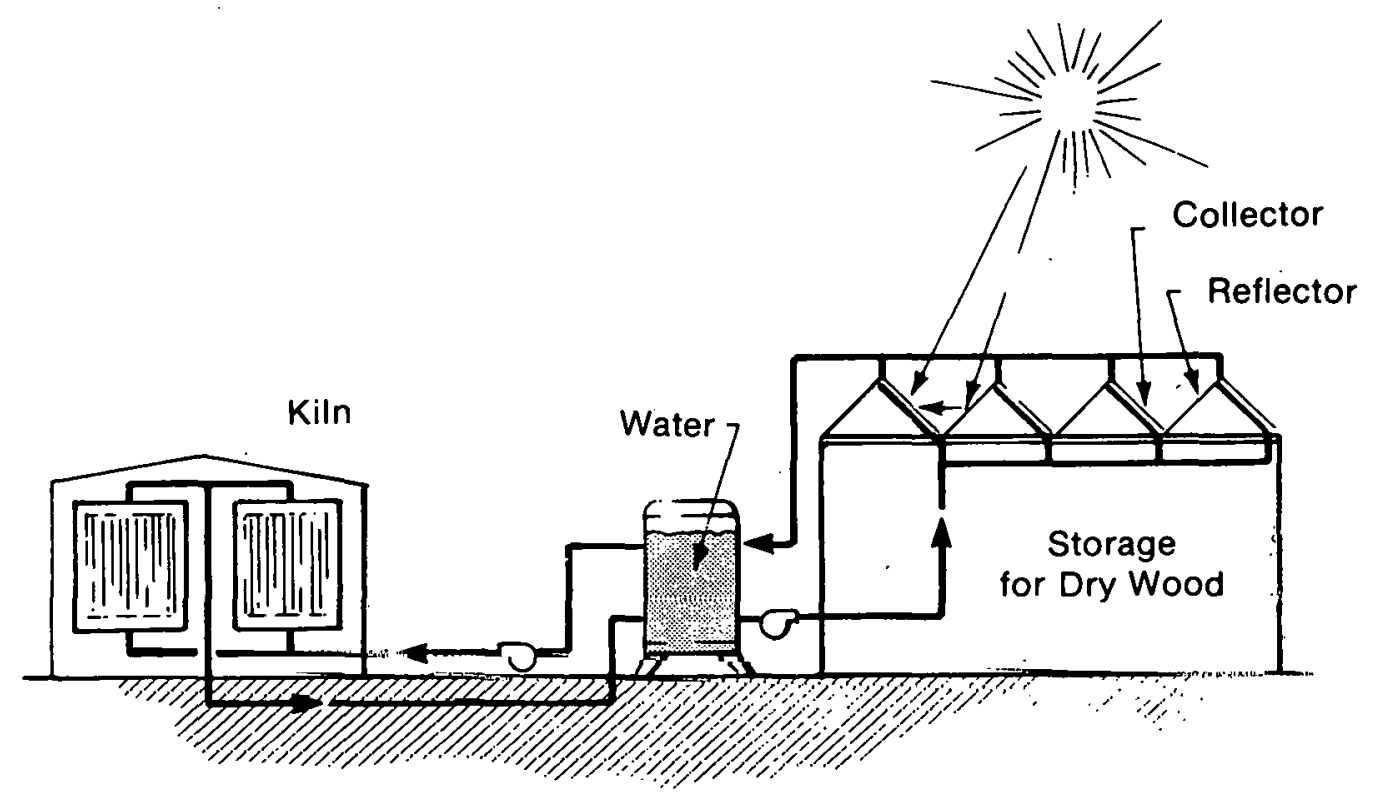

Figure 2-5. Solar Kiln Heating System Schematic (J. A. LaCour)

resulted. These problems were finally resolved by replacing the power supply and repairing the memory and analog-to-digital converter at a total cost of $\$ 3,000$. To prevent recurrence of this failure, all of the CPVC pipe was replaced with steel pipe, a high-temperature pump cutoff was installed, and the pressure relief valve was replaced with a larger une.

Although not as serious as water damage, dust has caused some problems with the disc drive. As a result, the shed housing the computer is now air conditioned and supplied with filtered air. The site of the lumber kiln is very dusty, and there was some concern that it would adversely affect collector performance. Huwever, the contractor has measured collector efficiency immediately before and after collector cleaning and has been unable to detect a difference.

Soon after installation, about 20 collectors exhibited outgassing, presumably from the insulation, and the glazings were replaced by the manufacturer. Inlet collectur manifold connections have broken a number of times due to overtightening during installation and have been replaced. A small amount of condensation has occurred on the collector glazings, but otherwise the collectors have not deteriorated appreciably. Obtaining complete drainage of the collectors has been somewhat of a problem, and several wooden sticks have been wedged in a makeshift fashlon under the collector piping to ensure adequate pipe slope.

Before some of the pipes to the heat exchangers were installed, they were evidently left on the ground and accumulated some gravel. Small pebbles became stuck in the target of the flowmeter (target/strain gauge type) causing it to read improperly. Grounding problems occurred on another target-type flowmeter. Although these flowmeters have been fixed, two turbine meters were installed to serve as a check, one of which has not operated properly. A failure of the differential thermostat also occurred, but this was quickly resolved. 
The solar system is designed to add heat to a kiln only when the gas furnace and blower are operating. Unfortunately, the minimum heat output of one of the burners is 200,000 $\mathrm{Btu} / \mathrm{h}$, which means that the solar system can only add heat in excess of this minimum. Since the average load for that kiln is $230,000 \mathrm{Btu} / \mathrm{h}$, there normally is little room left for the solar contribution. The other kiln has a minimum turndown of $100,000 \mathrm{Btu} / \mathrm{h}$ and is not as large a problem. The contractor hopes to install new gas valves, which will permit better turndown ratios.

Most recently, the data acquisition system was again rendered inoperable by water damage, though this time the system design was not at fault. Like Jackson, 20 miles to the south, the LaCour site was devastated by a flood in April 1979. Several feet of water penetrated the shed housing the data acquisition system and caused considerable damage. Although the solar system was operable within several days after the flood, the data acquisition system was still being repaired as of this writing.

The owners of the LaCour plant are very satisfied with the solar energy system. In combination with the backup heating system, the solar energy system allows lumber to be cycled through the kiln faster, especially reducing warmup time. The owners also feel that the solar heat is of better quality, since it permits higher humidity in the kiln, which is less likely to crack the wood than the hot combustion gases from the gas heat.

\subsection{LAMANUZZI AND PANTALEO FOODS, FRESNO, CALIF.}

This system, designed and built by the California Polytechnic State University in San Luis Obispo, Ca., provides hot air for the drying of fruits at the $\mathrm{L}$ and $\mathrm{P}$ Foods plant in Fresno, California. The solar system consists of $21,000 \mathrm{ft}^{2}$ of air collectors that supply hot air to a $14,000 \mathrm{ft}^{3}$ thermal storage bin and to 1 of 14 dehydration tunnels (see Fig. 2-6). A 12-ft diameter heat recovery wheel transfers heat from the tunnel exhaust to the fresh air collector inlet. During the drying season, prunes and raisins are stacked on trays and move through the gas-fired dehydration tunnels with a residence time of 24 hours. The ground-mounted solar collectors were fabricated by the contractor (including student labor) and assembled on-site.

The major visible problem at this site is the condition of the Lexan glazings on the collectors. The 0.020 -in Lexan cover plates have visibly yellowed, and many have cracked due to compression failure. Deterioration in collector array efficiency has not been observed, however, and analysis of a piece of glazing returned to SERI indicated a transmissivity of $\mathbf{8 0 \%}$, considerably better than a visual inspection might suggest.

A problem peculiar to this site is vandalism. Local gangs of youths have periodically come to the plant at night and caused damage. In one case, they broke up a portion of the viewing platform and struck the glazing with the boards. Fortunately, the Lexan was fairly resistant to this abuse. The vandals also carved their initials in the duct insulation.

The rock bin thermal storage unit is contained in a Butler shed and has had some minor problems. The rocks were loaded so quickly that thermocouples were knocked out of their desired positions. Also, the larger rocks tended to settle to the outside, resulting in less air flow in the center. Storage pressure drop is higher than was allowed for in fan selection, resulting in a $26 \%$ lower flow rate than planned and thus less heat stored.

Dampers have not had air leakage problems, although the damper controlling flow to the dehydrator had some oscillation problems, which required some modification of control 


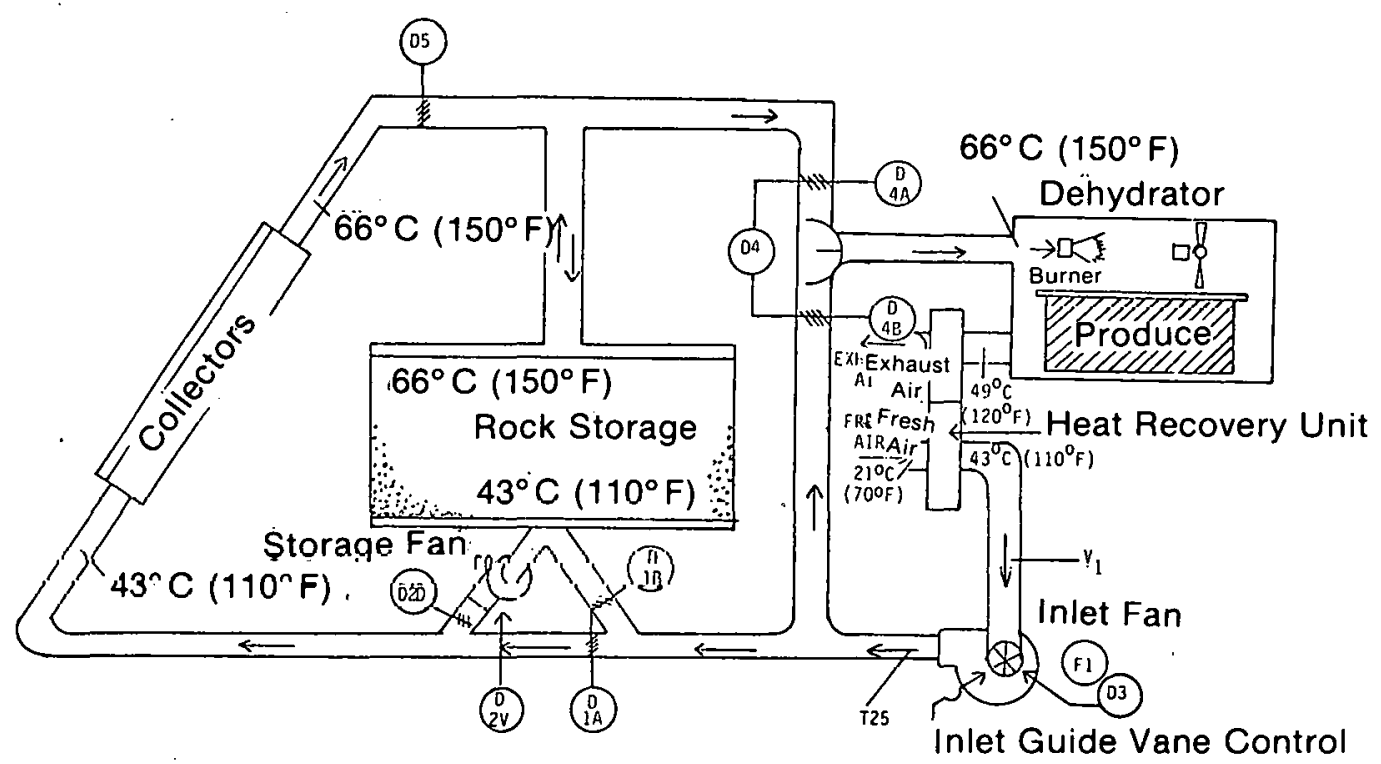

Figure 2-6. Schematic of Solar System (L and P Foods)

logic. Also, "weathertight" covers on dampers allowed rainwater to enter but not leak out. As a result, two damper motors had to be repaired. Heat losses from the ducls were higher than expected, probably due to a lack of insulation in inaccessible places and to uninsulated duct support straps.

The data acquisition and control systems have had several minor problems. The time clock on the solar system controller tended to lock sporadically and was eventually electrically decoupled by adding capacitors. The data logger has no battery backup and loses track of time when shut down. The data acquisition system records data on-site; the data is then transmitted via telephone line to the contractor's office in San Luis Obispo. It was decided to use a commercial rather than a dedicated telephone line, and coordination with the telephone company proved to be difficult.

In October 1979, the microprocessor that controls the solar system failed, and the system was shut down. It is thought that the failure occurred due to poor isolation of the controller inputs, so that one input was inadvertently connected to line voltage. The system has not yet been repaired.

The owners of $L$ and $P$ are apparently pleased with the solar energy system, although it has a much longer payback period than they require. Like many of the other owners, they are concerned with gas curtailment in the future and view solar energy as a possible way to alleviate this problem. 


\section{SECTION 3.0}

\section{PERFORMANCE RESULTS}

Figure 3-1 shows the status of the six projects during the operational periods. The bar graphs labeled "A" show when the solar system, the process, or both were operating. The bar graphs are based on daily operation data for Campbell Soup and York, monthly values for Riegel and L and P, quarterly averages for Gold Kist, and the complete period of operation for LaCour. There are clearly a few periods when the process was operating but the solar system was not, notably for York and $L$ and $P$. The 1-1/2 month outage for York corresponds to the repair of the frozen heat exchanger. $\mathrm{L}$ and $\mathrm{P}$ has been down since mid-October, 1979, due to the failure of its controller. In general, however, solar system availability has been high for these projects.

Utilization of the solar system presents a different picture. Gold Kist and L and P Foods both show extensive periods when the solar system was available but the process was not operating. This of course is linked to the seasonal nature of drying operations. At the $L$ and $\mathrm{P}$ plant, for example, no fruits are available for drying from mid-January through the end. of July. (Explicit definitions and values for the availability and utilization of each project are given later in this section.)

The bar graphs labeled "B" in Fig. 3-1 show the performance of the data acquisition system for each project; that is, the time periods for which reduced data is available. It is clear that data acquisition has been a very serious problem at Campbell Soup and Riegel Textile and, to a lesser extent, at York and LaCour. With the exception of LaCour, which has on-site data reduction, all of the projects record raw data on a data logger and then process the data at the contractor's office. There are cases (notably at Riegel Textile) where raw data has been recorded, but much of it has not been reduced and is thus unavailable. At the Gold Kist plant, data (including insolation) has been taken only during solar system operation. To compound the problem, each contractor is measuring different quantities, and the data that is reduced is not reported in a uniform manner.

As a result of these problems, it is no simple matter to compare the performance of the different projects. Since reduced data is of ten only available for short periods of time, monthly or annual energy values cannot be compared. Instead, energy parameters have been summed for each project and divided by the number of days over which the param eters were measured. This essentially yields an average "per day" value of the parameter. Of course, if one project recorded data only during cold months or cloudy days, and another has data available only for warm months or sunny days, comparing energy collected per day for the two projects is misleading. Unfortunately, the amount of data available does not allow a more controlled analysis.

A number of parameters affect performance as well. Type of collector, site location, process temperature, load profile, and state of repair all have important impacts on energy collected. Thus, although it is interesting to see how one project compares to the others, the various parameters must all be kept in mind. It is also valuable to consider the performance of a given project in light of how well it could perform if it were not a first-generation design.

Tables 3-1 (A and B) summarize the system performance parameters for the six projects. The number of days of data upon which these numbers are based is given so that the statistical significance of the results can be better understood. Note that for the Riegel 


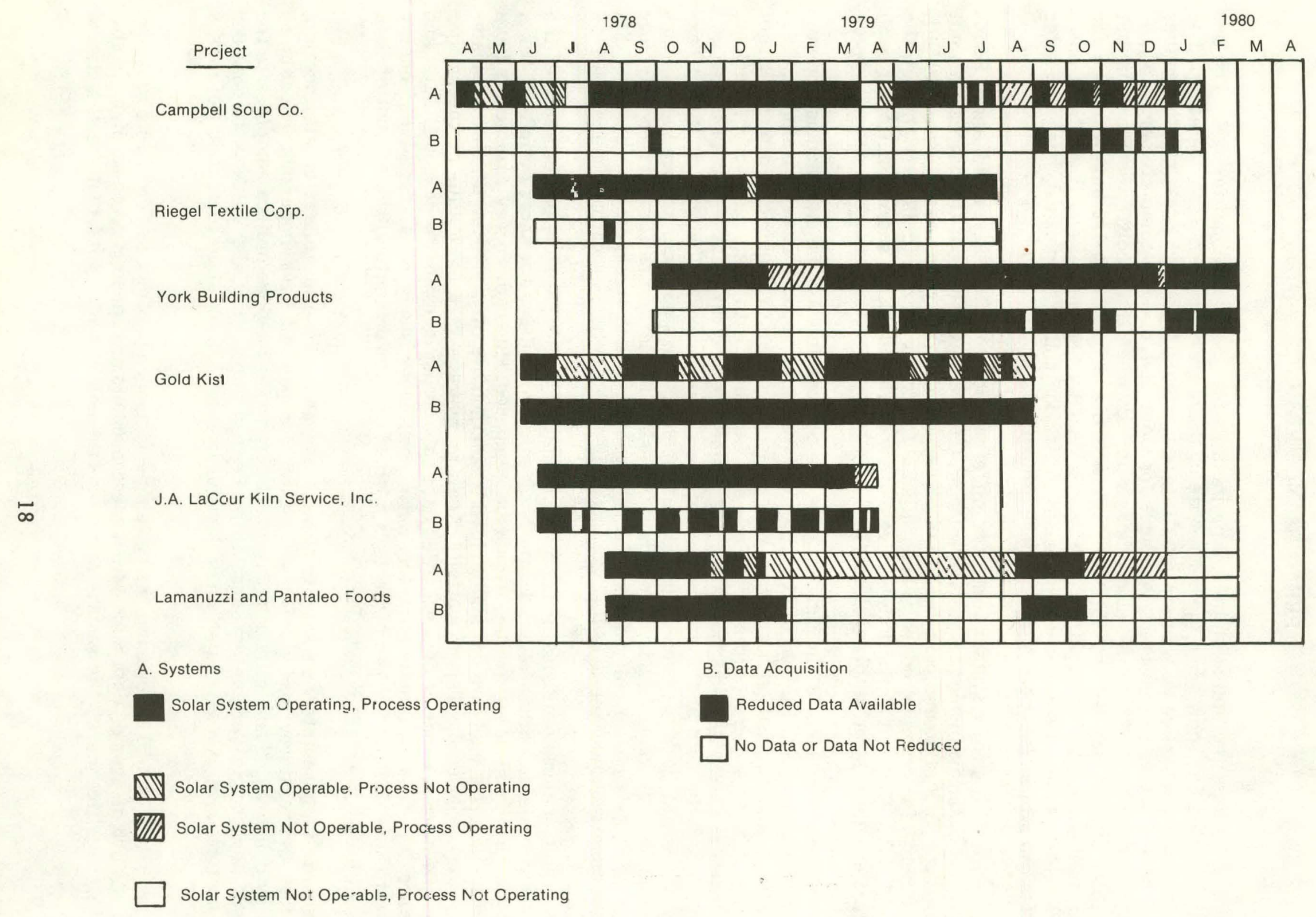

Figure 3-1. System and Data Acquisition Availability/Utilization Graph 
Table 3-1A. SYSTEM PERFORMANCE OF IPH FIELD TESTS

\begin{tabular}{|c|c|c|c|c|c|c|c|}
\hline Project & $\begin{array}{c}\text { No. Days } \\
\text { Date }\end{array}$ & $\begin{array}{c}\text { Incident } \\
\text { Solar Energy } \\
\text { (MBtu/day) }\end{array}$ & $\begin{array}{c}\text { Energy } \\
\text { Collected } \\
\text { (MBtu/day) }\end{array}$ & $\begin{array}{l}\text { Parasitic. } \\
\text { Energy Use } \\
\text { (MBtu/day) }\end{array}$ & $\begin{array}{c}\text { Energy } \\
\text { Delivered } \\
\text { (MBtu/day) }\end{array}$ & $\begin{array}{c}\text { Energy } \\
\text { Delivered/Area } \\
\text { (Btu/ } / \mathrm{ft}^{2} \text { day) }\end{array}$ & $\begin{array}{c}\text { Fuel } \\
\text { Displaced }\end{array}$ \\
\hline Campbell Soup & 62 & 11.32 & 3.57 & 0.15 & - & - & Natural gas \\
\hline Riegel Textile & 3 & 11.0 & 2.01 & 0.068 & 1.07 & 160 & Fuel oil \\
\hline $\begin{array}{l}\text { York Building } \\
\text { Products }\end{array}$ & 262 & 11.05 & 1.30 & 0.051 & 1.09 & 118 & Fuel oil \\
\hline Gold Kist & . 290 & 13.3 & 3.49 & 0.31 & 3.40 & 260 & $\begin{array}{l}\text { Fuel oil, } \\
\text { Natural gas }\end{array}$ \\
\hline $\begin{array}{l}\text { LaCour Kiln } \\
\text { Services }\end{array}$ & 180 & 3.22 & 1.17 & 0.012 & 1.08 & 429 & Netural gas \\
\hline$L$ and $P$ Foods & 181 & 47.8 & 10.5 & 1.00 & 9.49 & 452 & Natural gas \\
\hline
\end{tabular}

${ }^{a}$ Daily total insolation in the plane of the collector array.

${ }^{b}$ Performance results available for this sites are included for information, but poor statistical basis should be noted.

Table 3-1B. SYSTEM PERFORMANCE OF IPH FIELD TESTS

\begin{tabular}{|c|c|c|c|c|c|c|c|}
\hline Projont & $\begin{array}{c}\text { No. Days } \\
\text { nata }\end{array}$ & $\begin{array}{c}\text { System } \\
\text { Utilization } \\
(\%)\end{array}$ & $\begin{array}{c}\text { System } \\
\text { Availability } \\
\text { (क) }\end{array}$ & $\begin{array}{c}\eta_{c} \\
\text { Collector } \\
\text { Array Efficiency } \\
(\%)\end{array}$ & $\begin{array}{c}\eta_{\mathrm{T}} \\
\text { Thermal System } \\
\text { Efficiency } \\
(x)\end{array}$ & $\begin{array}{c}\eta_{s} \\
\text { Net System } \\
\text { Efficiency } \\
(\%)\end{array}$ & $\begin{array}{c}\text { Parasitic }^{\mathbf{a}} \\
\text { Fraction } \\
(\%)\end{array}$ \\
\hline Campbell Soup & .62 & 81.5 & 82.0 & 31.5 & - & - & 4.2 \\
\hline Riegel Textile & 3 & 97.0 & 97.6 & 18.3 & 9.7 & 8.1 & 3.4 \\
\hline $\begin{array}{l}\text { York Building } \\
\text { Products }\end{array}$ & 2.62 & $\ln n . n$ & 91.6 & 11.7 & 9.8 & 8.6 & 3.9 \\
\hline Gold Kist & 290 & 63.5 & 100.0 & 26.2 & 25.6 & 19.7 & 8.7 \\
\hline $\begin{array}{l}\text { LaCour Kiln } \\
\text { Services. }\end{array}$ & 180 & 100.0 & 94.0 & 36.3 & 33.5 & 32.5 & 1.0 \\
\hline L and P Foods & 181 & 41.4 & 72.2 & 22.1 & 19.9 & 14.2 & 9.5 \\
\hline
\end{tabular}

a [Parasitic energy (MBtu) $\div$ Energy Collected (MBtu) $\times 100 \%$.

${ }^{b}$ Performance results available for this sites are included for information, but poor statistical basis should be noted. 
Textile plant only three days of data are available. Performance results based on this data are included for information, but the poor statistical sample available for this project compared to the other projects should be kept in mind.

The utilization column in Table 3-1B refers to that fraction of time the solar system was actually used by the process during the time that the system was available. The availability refers to the fraction of time the solar energy system was available to supply energy to the process during the period of interest. The availability does not take into account climatic conditions that might render the system unusable, but refers only to the mechanical reliability of the solar system.

Specifically,

Solar System Utilization $=$

Periods of Solar System Operation

Total Period of Study - Periods of Solar System Downtime $\times 100 \%$, and

Solar System Availability =

$\frac{\text { Total Period of Study - Periods of Solar System Downtime }}{\text { Total Period of Study }} \times 100 \%$,

where solar system downtime refers to those periods of time when the solar system was inoperable due to mechanical failure, and the period of study refers to the overall period of interest.

The availability has been based on the total period of study rather than on the plant operation time so that it shows all periods of solar system downtime, even if the industrial plant happens to be down at the same time. The utilization is based on the period of time the solar system was available to produce energy so that it measures the use of the system by the plant without penalizing for periods when the solar system was down. The definitions allow the factors for utilization and availability to be multiplied together to give an overall system operation factor, which is the period of solar system operation divided by the total period of study. Ideally, an industrial project would use solar energy all year (high utilization), and its solar energy system would be reliable enough to supply its portion of the load whenever called upon (high availability).

The incident solar radiation values given in the table refer to the total daily insolation in the plane of the collectors (direct and diffuse) incident upon the total collector array area. For the York plant, the insolation is calculated at $15^{\circ}$ from the horizontal, which is the tilt angle of the array mounting. For the Campbell Soup plant, the tilt angle of the flat-plate collectors is used. The energy collected is equal to an integral over time of the quantity $\dot{m} C_{p} \Delta T$, where $\dot{m}$ is the collector mass flow rate, $C_{p}$ is the specific heat of the collector fluld, and $\Delta \mathrm{T}$ is the difference between collector infet and outlet fluid temperatures. The energy delivered is defined as the energy actually supplied to the process from the solar system. It entails a similar calculation to that for the collected energy 
but varies with each site; it is essentially the collected energy minus the thermal losses in the rest of the system.

Collector array efficiency, $\eta_{c}$, is an overall time-average value calculated by dividing the average energy collected in a day by the daily solar radiation incident on the collector array, $\mathrm{I}_{\mathrm{T}} \mathrm{A}_{\mathrm{a}^{*}}$. Thermal system efficiency, $\eta_{\mathrm{T}}$, takes into account all thermal losses in the system. Thus,

$$
\begin{gathered}
\eta_{\mathrm{c}}=\frac{\text { Energy Collected }}{\mathrm{I}_{\mathrm{T}} \mathrm{A}_{\mathrm{a}}} \times 100 \% \text {, and } \\
\eta_{\mathrm{T}}=\frac{\text { Energy Collected }- \text { Thermal Losses }}{\mathrm{I}_{\mathrm{T}} \mathrm{A}_{\mathrm{a}}} \times 100 \%=\frac{\text { Energy Delivered }}{\mathrm{I}_{\mathrm{T}} \mathrm{A}_{\mathrm{a}}} \times 100 \% .
\end{gathered}
$$

The parasitic energy reported in Table 3-1A is the daily electrical energy use of pumps, fans, trackers, etc., required by the solar system, expressed in MBtu/day. In the last column of Table 3-1B, this is expressed as a percentage of the energy collected. In order to show the effects of parasitic power on system efficiency, the net system efficiency given in Table $3-1 B$ is defined as:

$$
\eta_{\mathbf{S}}=\frac{\text { Energy Delivered }-(\xi \times \text { Parasitic Energy })}{\mathrm{I}_{\mathrm{T}} \mathbf{A}_{\mathbf{a}}} \times 100 \%
$$

The factor $\xi$ is the ratio of the efficiency with which the on-site boiler would utilize displaced fossil fuel to the overall efficiency with which a central electric generating plant would utilize that fuel [2]. If one takes an average on-site efficiency of 0.70 and a central plant efficiency of 0.26 (including distribution losses), $\xi$ becomes 0.70 divided by 0.26 , or 2.7. Thus, one Btu of parasitic electricity is considered to be worth $2.7 \mathrm{Btu}$ of fossil fuel.

Table 3-1B shows collector array efficiencies varying from $11.7 \%$ at York to $36.3 \%$ at LaCour. The very low array efficiency for York is due in part to the fact that this site has experienced very hazy weather. Since the concentrators collect only direct radiation, and both direct and diffuse radiation are included in the array efficiency calculations, the efficiency calculated is quite low. Certainly, the deterioration of the absorber coating has also affected collector performance. The Campbell Soup efficiency is based on hand calculations, and errors are estimated at $10 \%$ or more. The collector array efficiency for $L$ and $P(2.2 .1 \%)$ would be higher if the ambient air supplied to the collector inlet were not preheated by the heat recovery wheel.

The somewhat low (18.3\%) collector array efficiency for the Riegel evacuated tubes compared to expected evacuated tube efficiencies can be attributed partly to the lower than expected flow rate, header pipe losses, and contamination of the reflectors discussed earlier. A major factor in the high efficiency (36.3\%) for the LaCour array is the large area of planar reflectors used. The efficiency is calculated based on the total insolation striking only the collectors, so the result is high. Since the reflectors are 
much cheaper than the collectors, however, and do not increase the roof area needed to accommodate the sawtooth collector array, this is probably a fair basis for calculation. In any case, the radiation striking the plane of the reflectors was not measured and cannot be included in the calculation. (Estimating that the reflectors might increase the insolation by $25 \%$ results in a collector/reflector array efficiency of about $29 \%$.)

Figure 3-2 shows for each project the collector array efficiency, the thermal system efficiency (including thermal losses in piping), and the net system efficiency. For several of the projects, thermal system efficiencies are on the order of three to five percentage points lower than collector array efficiencies. However, for the Riegel plant, thermal system efficiency is considerably lower than that of the collector array. The discrepancy between system and collector efficiency at Riegel (9.7\% versus $18.3 \%$ ) is due to thermal losses in piping and overnight losses from the collector inventory. The Riegel plant also has a high parasitic energy percentage (3.4\% of collected energy), probably because of long pipe runs and serpentine flow in the collectors.

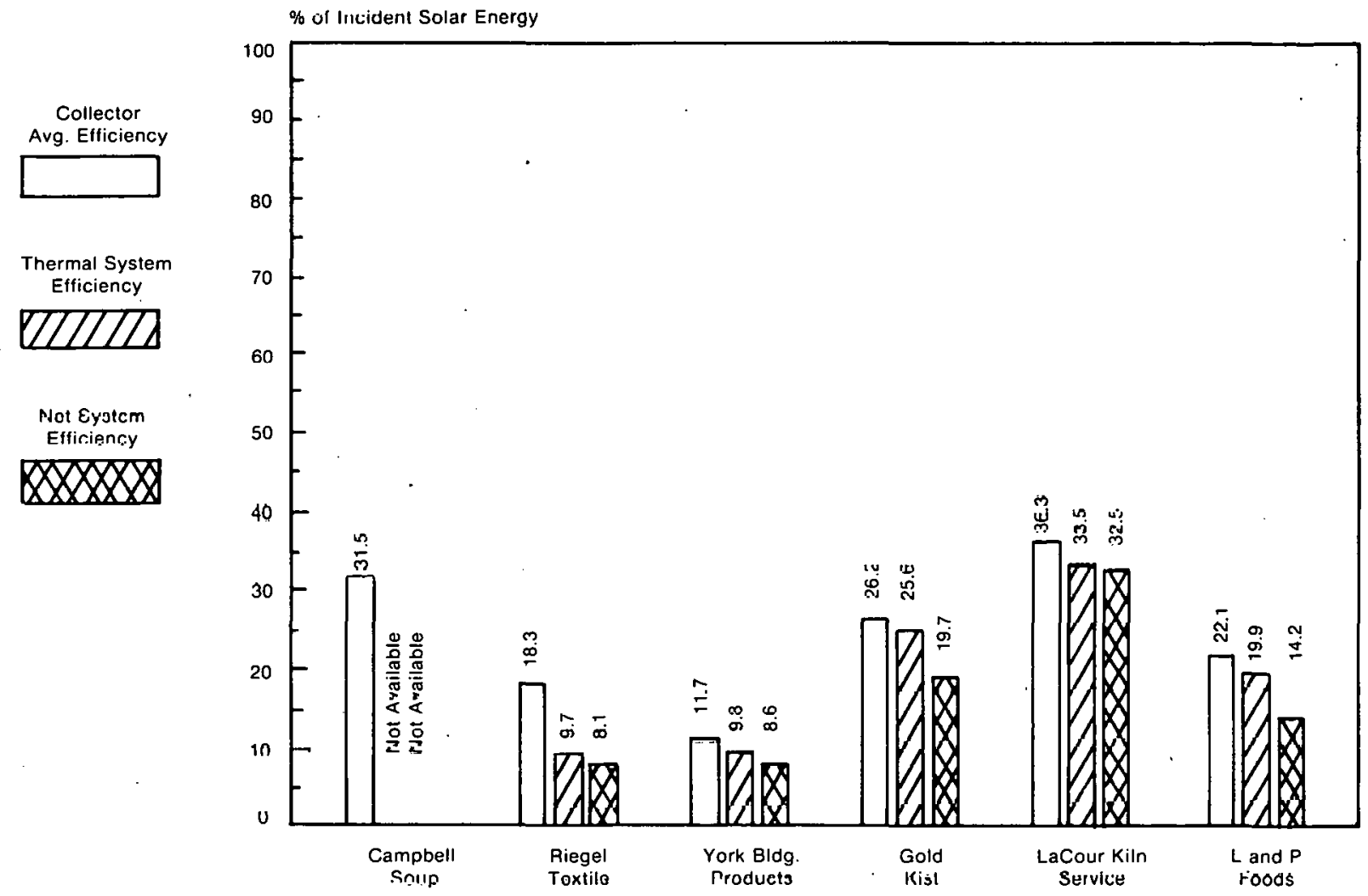

Figure 3-2. Efficiencies of the DOE-IPH.Field Tests

Parasitic power requirements have been high in the two projects using air collectors. Parasitic energy consumptions of $0.31 \mathrm{MBtu} /$ day for Gold Kist and $1.00 \mathrm{MBtu} /$ day for $\mathrm{L}$ and $\mathrm{P}$ are considerably higher than for the other projects. They represent $8.7 \%$ and $9.5 \%$, respectively, of collected energy, as compared to a range of $1.0 \%$ to $4.2 \%$ for the other projects. In both cases, fan power is the culprit. The particularly low efficiency for $\mathrm{L}$ 
and $P$ is probably due largely to pressure drop across the rock bin. As a result, net system efficiencies for these two projects (19.7\% and $14.2 \%)$ are considerably lower than thermal system efficiencies (25.6\% and $19.9 \%)$.

The performance of the various projects may also be presented by normalizing energy delivered in terms of the amount of collector area. The average energy delivered per day per square foot of collector is given in the Energy Delivered/Area column of Table 3-1A. The highest value, $452 \mathrm{Btu} / \mathrm{ft}^{2}$-day, is for the $\mathrm{L}$ and $\mathrm{P}$ plant. This is probably due largely to the fact that this plant is located in an area of high insolation. The other projects range from $118 \mathrm{Btu} / \mathrm{ft}^{2}$-day for York to $429 \mathrm{Btu} / \mathrm{ft}^{2}$-day for LaCour. Again, the Riegel system's performance has been hampered by low collector array efficiencies and high thermal losses. It is also important to note that this system has been supplying much hotter fluid than the other systems (as high as $270^{\circ} \mathrm{F}$ ). The higher the temperature, the greater the effects of thermal losses become.

Because of the problems with data acquisition systems, it is not known how much total energy each system has delivered since becoming operational. If this data were available, however, it would probably show a fairly wide variation. The weather has not been very cooperative at several sites. At the LaCour kiln in Canton, Miss., for example, the winter (1978-79) was a very rainy one with very little sunshine during December and January. As mentioned previously, the York plant experienced very hazy weather, and as a result the amount of direct radiation available to the concentrating collectors was low. Concentrators were originally selected to supply $180^{\circ} \mathrm{F}$ water to the rotoclave; however, it has since been found that the rotoclave works well with water at temperatures as low as $135^{\circ} \mathrm{F}$. Considering the lower process temperature and high amount of diffuse radiation, flat-plate collectors might well have provided more energy.

Little attempt has been made to accurately measure the amount of fossil fuel displaced. Generally, a boiler efficiency is assumed, and based upon the solar energy delivered, an equivalent amount of fuel oil or gas is calculated. Fuel displacement is then simply proportional to energy delivered. Also, attempting to compare the projects based on the amount of fuel displacement can be misleading. At the LaCour kiln, the same amount of gas is used, but solar energy allows more lumber to be processed. Thus, the amount of gas used per board foot of lumber has decreased. At the Gold Kist plant the burners have not been modified to use less fuel with the warmer combustion air, and so, rather than saving fuel, the solar energy is making the soybeans slightly dryer. The amount of air supplied by the collectors, however, is so small compared to the combustion air required by the burners that solar energy is supplying less than $2 \%$ of the energy required. (When parasitic power is considered, the number is lower still.) With a solar fraction this small, actual numbers are not meaningful, since they are less than the measuring accuracy, or to put it another way, they are in the "noise" level of the system.

Besides saving fuel, there are intangible ways that solar energy can be of benefit. It has been mentioned that the owners at LaCour believe that the solar heat provides a more humid environment for wood drying and results in a better quality product. It might also be speculated that solar energy used to dry crops provides a better product than combustion drying does. No tests have been made to check this, though the Department of Agriculture inspector at the $L$ and $P$ plant has detected no difference between solar-dried and gas-dried raisins.

A word should be said about energy conservation in these plants. In most cases, no detailed energy conservation measures were taken in conjunction with the installation of the solar system. The $\mathrm{L}$ and $\mathrm{P}$ dehydration plant, which employs a heat recovery wheel, 
is a notable exception. Data indicates that the heat recovery wheel has provided more than 2-1/2 times as much energy to the dehydrator as the solar system and has a payback period of less than one year. The contractor for this project has pointed out several other energy conservation measures that could be used in this plant and that would provide rapid payback. Indications are that, in this respect, the $L$ and $P$ plant is not unusual. The purpose of these field tests was, of course, to demonstrate the use of solar energy in industrial processes, not energy conservation. It is evident, however, that energy conservation should precede solar implementation in commercial industrial applications-precisely the principle that has been recognized in building heating and cooling applications for some time.

While it is interesting to learn how the field tests compare to each other in terms of performance, it is also enlightening to compare actual with predicted performance. This is done in Table 3-2. It is readily apparent that in all cases the actual annual delivered energy is much less than predicted. (Section 4.0 details the way in which actual annual energy delivery values were calculated.)

Whereas system design of solar heating and cooling of buildings is of ten done with the aid of predictive models such as F-CHART, TRNSYS, etc., there are as yet no such tools available for IPH. As a result, each contractor did his own calculations using different assumptions, and the figures in Table 3-2 cannot be used to evaluate the accuracy of any recognized design techniques. Reasons for the discrepancies between actual and predicted energy deliveries include overprediction of insolation and the assumption that no outages (such as to repair a heat exchanger) would occur. In general, however, the two major causes of the poor predictability were overestimation of collector array performance (e.g., failure to account sufficiently for field degradation and header losses) and failure to adequately estimate piping losses both during operation and overnight.

Table 3-2. PREDICTED AND ACTUAL ENERGY DELIVER OF IPH FIELD TESTS

\begin{tabular}{lcccc}
\hline & \multicolumn{4}{c}{ Annual Energy Delivery } \\
\cline { 2 - 5 } \multicolumn{1}{c}{ Project } & $(\mathrm{MBtu} / \mathrm{yr})$ & $(\mathrm{Btu} / \mathrm{yr}) / \mathrm{ft}^{2}$ & $(\mathrm{MBtu} / \mathrm{yr})$ & $(\mathrm{Btu} / \mathrm{yr}) / \mathrm{ft}^{2}$ \\
\hline Campbell Soup & 2156 & 290,000 & - & - \\
Riegel Textile & 1400 & 210,000 & 370 & 55,000 \\
$\begin{array}{l}\text { York Building } \\
\text { Products }\end{array}$ & 1500 & 160,000 & 364 & 39,000 \\
Gold Kist & 3700 & 280,000 & 788 & 60,000 \\
$\begin{array}{l}\text { LaCour Kiln } \\
\text { Services }\end{array}$ & & & & 147,000 \\
L and P Foods & 2300 & 360,000 & 370 & 49,000 \\
\hline
\end{tabular}




\section{SECTION 4.0}

\section{$\operatorname{cosTs}$}

No attempt has been made in this study to obtain a detailed cost breakdown for these projects. Instead, gross costs have been summarized so that projects can be compared on a $\$ /(\mathrm{MBtu} / \mathrm{yr})$ and $\$ / \mathrm{ft}^{2}$ basis. The Department of Energy has funded these projects in three phases: Phase 1, Design; Phase 2, Construction; and Phase 3, Operation.

Costs for Phases 1 and 2 are given in the first 2 columns of Table 4-1. The sum of these costs (total capital cost) is given in column 3. Since future privately funded projects would incur considerably lower design costs and would not employ detailed data acquisition systems, column 4 lists Phase 2 costs minus data acquisition costs.

Column 6 of Table 4-1 lists energy delivered for each project in terms of MBtu/day. For purposes of comparison, the values of MBtu/day have been extrapolated to obtain the number of MBtu that would have been delivered during the first year of operation had the system performed at all times as it did during the periods for which data was available. (The extent of the extrapolation needed for each project depends on the number of days of available data. For the Riegel Textile plant, for example, a large extrapolation was required.) The values of $\mathrm{MBtu} / \mathrm{yr}$ for the first year of operation thus obtained are given in column 7.

The lifetimes of these systems are not yet known, so current economic analysis techniques use the total cost of the system divided by the energy delivered by the system over the first year as the quantity for comparison. For these projects, the values of $\$ /(\mathrm{MBtu} / \mathrm{yr})$ are given in two forms. Column 8 gives the figures based on total capital cost, and column 9 considers only Phase 2 costs minus data acquisition costs. Columns 10 and 11 list the system costs in terms of $\$ / \mathrm{ft}^{2}$, again on the two different cost bases.

Based on total capital cost, the projects vary from $\$ 786 /(\mathrm{MBtu} / \mathrm{yr})$ to $\$ 2348 /(\mathrm{MBtu} / \mathrm{yr})-$ an average of $\$ 1392 /(\mathrm{MBtu} / \mathrm{yr})$. Based on energy delivery, the least expensive project is $\mathrm{L}$ and $\mathrm{P}$, due to the low cost of the collector array (see below). The most expensive projects on the same basis are the Riegel and York plants. Although the Riegel plant was the second highest in capital cost, it had the highest cost in terms of energy delivery due to its low system efficiency. The York energy cost is high due to the very low collector array efficiency for that project. The Gold Kist plant was only slightly less expensive, its high cost due largely to its expensive support structure. When design and data acquisition costs are omitted, the cost range becomes $\$ 499 /(\mathrm{MBtu} / \mathrm{yr})$ to $\$ 1537 /(\mathrm{MBtu} / \mathrm{yr})$-an average of $\$ 927 /(\mathrm{MBtu} / \mathrm{yr})$.

Again, it must be noted that these results are based on fragmentary data. Also, plant performance can be expected to improve considerably in the next year. The three hot water projects are all in the process of being upgraded. For the Riegel plant, in particular, there is optimism that many of the thermal losses that limited performance can be corrected.

The costs of these projects in terms of $\$ / \mathrm{ft}^{2}$ hque a much wider variation than those based on energy delivery, ranging from $\$ 38.80 / \mathrm{ft}^{2}$ to $\$ 142 / \mathrm{ft}^{2}$ based on total capital cost (an average of $\$ 93 / \mathrm{ft}^{2}$ ). Most noticeable is the very low cost for the $\mathrm{L}$ and $\mathrm{P}$ project. The contractor on this project was a university, and the professor and his students built the collectors themselves and assembled them on-site. Students were paid standard union wages, but overhead costs were very low. The site assembly and use of low-cost 
Table 4-1. COSTS OF THE LOW-TEMPERATURE IPH FIELD TESTS

\begin{tabular}{|c|c|c|c|c|c|c|c|c|c|c|c|}
\hline Pro:ect & $\begin{array}{c}\text { Design, } \\
\text { Phese II } \\
(\$)\end{array}$ & $\begin{array}{l}\text { Construc-ion, } \\
\text { Phase } \bar{z} \\
(\$)\end{array}$ & $\begin{array}{c}\text { Total Capital } \\
\text { Cost, Phase I } \\
\text { \&c Phase? } \\
\text { (\$) }\end{array}$ & $\begin{array}{c}\text { Phase } 2 \\
\text { - Date: } \\
\text { Acquisition }\end{array}$ & $\begin{array}{l}\text { Number } \\
\text { Days } \\
\text { of Data }\end{array}$ & $\begin{array}{l}\text { MBtu/ tay } \\
\text { delivered }\end{array}$ & $\begin{array}{c}\text { Extrapolated } \\
\mathrm{MBtu} / \mathrm{yr}\end{array}$ & $\begin{array}{l}\text { Extrapolated } \\
\$ /(\mathrm{MBtu} / \mathrm{yr})^{\mathrm{a}}\end{array}$ & $\begin{array}{l}\text { Extrapolated } \\
\$ /(\text { MBtu/yr) }\end{array}$ & $\left(\$ / \mathrm{ft}^{2}\right)^{\mathrm{a}}$ & $\left(\$ / \mathrm{ft}^{2}\right)^{\mathrm{b}}$ \\
\hline Campbell Soup & 204,280 & $580,87)$ & 785,150 & 549,005 & 62 & - & - & - & - & 107.0 & $\overline{74.8}$ \\
\hline Riegel Textile & 258,310 & $6: 0,351)$ & 868,660 & 568,735 & 3 & 1.07 & 370 & $\approx 348^{\mathrm{C}}$ & $1537^{\mathrm{C}}$ & 130.0 & 85.1 \\
\hline $\begin{array}{l}\text { York Building } \\
\text { Products }\end{array}$ & $11+, 200$ & $4 \leq 9,001]$ & 563,200 & 394,510 & 262 & 1.09 & 364 & $: 547$ & 1084 & 61.1 & 42.8 \\
\hline Gold Kist & 286,760 & $7 \leq 7,91 \mathrm{~J}$ & $1,034,670$ & 726,160 & 290 & 3.40 & 788 & 313 & 922 & 79.0 & 55.4 \\
\hline $\begin{array}{l}\text { LaCour Kiln } \\
\text { Services }\end{array}$ & $7: .300$ & $285,80 ! 3$ & 357,106 & 219,555 & 180 & 1.08 & 370 & 965 & 593 & 142.0 & 87.1 \\
\hline$L$ and $P$ Foods & 268,890 & $5 \leq 5,001]$ & 813,896 & 517,000 & 181 & 9.49 & 1035 & 786 & 499 & 38.8 & 24.6 \\
\hline
\end{tabular}

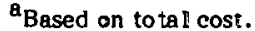

besed on Phase 2 minus data acquisition arst.

${ }^{c}$ Cost results for this site are included for infor ration, but poor statistical besis should be noted.

Note: In order tq put the costs of these first-generation tests in perspective, each contractor was asked to project how much his system would cost if it consisted of $100,000 \mathrm{ft}^{2}$ of $\mathrm{col}=\mathrm{cto}$ :, and were tailt ir: 1982, assurring the froblems that occurred in these first tests were prevented. Their response based on construction costs only were as foll.rws: Acurez (CEmpbe1 Soup) - $\$ 121 / \mathrm{MBtL} / \mathrm{yr}$ ), $\$ 36 / \mathrm{ft}^{2}$; AAI (York) - $\$ 270 /(\mathrm{MBtu} / \mathrm{yr}), \$ 30 / \mathrm{ft}^{2}$; Treledsne-Brqwn (Gold Kist) - $\$ 292 /(\mathrm{MBtu} / \mathrm{yr}$ ), $\$ 31 / \mathrm{ft}^{2}$; Lockheed (LaCour) - $\$ 177$; (MBtL/yr), $\$ 40 ; \mathrm{ft}^{2}$; Cali fornia Poiytechnic State University (L\&P) - $\$ 157 /(\mathrm{MBtu} / \mathrm{yr}), \$ \vdots 6.1 / \mathrm{ft}^{2}$. These costs are based on 1980 dollars, whereas the costs in the table are in 1977 dollers. Ne cost est mate was received from General Elec tric (Riegel) in time for publication. 
materials contributed toward making this the least expensive project based on collector area. With design and data acquisition costs excluded, the cost range for all projects is $\$ 24.60 / \mathrm{ft}^{2}$ to $\$ 87.10 / \mathrm{ft}^{2}$ (an average of $\$ 61.63 / \mathrm{ft}^{2}$ ). N te that this greatly reduces the cost of the LaCour project (from $\$ 142 / \mathrm{ft}^{2}$ to $\$ 87.10 / \mathrm{ft}^{2}$ ). Since this project has such a small collector area $\left(2,520 \mathrm{ft}^{2}\right)$, design and data acquisition constitute a large fraction of the cost.

Because of the limited cost and performance data available and the large probable difference between first-year performance and future performance, no attempt has been made to perform a life-cycle cost analysis for these projects. Certainly, payback periods will be longer than 20 years and in some cases much longer.

Since these were first-round projects, future prices can be expected to drop considerably. For example, in the first three rounds of government-funded solar heating/hot water projects for commercjal buildings, average costs (excluding design and data acquisition) dropped from $\$ 122 / \mathrm{ft}^{2}$ to $\$ 48 / \mathrm{ft}^{2}$. Also, privately funded projects can be expected to be lower in cost than government-funded projects due to lower overhead and indirect costs and more conventional construction scheduling and management techniques.

While cost payback is a much discussed question, it must also be considered that each project will require a certain amount of time to pay back the amount of energy used in its construction. Although this question has not generally been addressed, E. J. Carnegie et al. of California Polytechnic State University collected data on the energy embodied in materials and equipment used in the $L$ and $P$ project [3] and calculated the energy payback period. The embodied energy per unit cost of this system was found to be $44,000 \mathrm{Btu} /$ dollar compared to $70,900 \mathrm{Btu} /$ dollar for industrial buildings (which do not displace energy). For the $\mathrm{L}$ and $\mathrm{P}$ plant, which has a six-month drying season, the energy embodied in the system was calculated to have a payback period of approximately five seasons. If no heat recovery wheel were used, this period would be considerably longer. Of course, this payback period is not of concern to the industrial owner who sees an immediate energy savings. It is important, however, in calculating the effect of solar implementation in displacing the nation's use of fossil fuels. 
SEPI僖 


\section{SECTION 5.0}

\section{CONCLUSIONS}

Although the limited statistical basis available from the six projects makes generalization difficult, some conclusions can be drawn that should prove useful in future projects. These are:

- Collectors can prove to be a major problem in field application of solar projects. Degradation of absorber surfaces and glazings is still relatively common.

- Problems similar to those encountered in the solar heating and cooling of buildings programs occur in IPH applications. Better education in system design, engineering; and installation is needed to prevent the reoccurrence of problems such as: thermal shocking of evacuated tube collectors, heat exchanger freezing due to thermosiphon heat loss, improper pump selection, etc.

- Parasitic power has been a major factor in the low system efficiency of the two systems employing air collectors.

- Thermal losses from piping, both during operation and overnight, can seriously degrade system performance.

- Data acquisition systems have generally been very unreliable.

- Solar energy application to industrial process heat is not yet cost effective. Although industrial managers are concerned with fuel curtailments, most do not yet view solar energy as a profitable investment.

- A considerable investment in maintenance is needed to approach predicted performance in first-generation projects.

- Environmental contaminants can seriously affect solar collector performance.

- Certain adjustments in plant operation schedules, hardware, and control logic are often needed to optimize the utilization of a solar energy system.

- Energy conservation opportunities are abundant in industry and many have much more rapid payback periods than solar energy systems. Just as in the solar heating and cooling of buildings, energy conservation should precede solar implementation.

- In some applications, solar energy may improve the quality of a final product, in addition to saving fossil fuel. 


\section{S=Plo}




\section{SECTION 6.0}

\section{REFRRENCES}

1. U. S. Department of Energy. Proceedings: Volume 1 Solar Industrial Process Heat Conference. October 18-20, 1978. SERI/TP-49-065. Idaho National Engineering Laboratory. Golden, CO: Solar Energy Research Institute.

2. Preconference Proceedings-Solar Heating and Cooling Systems Operational Results. November 27-30, 1979. SERI/TP-49-063. Golden, CO: Solar Energy Research Institute.

3. Carnegie, E. J., et al. "Operation of an Industrial Solar Drying System." Proceedings of the 1979 Annual Meeting. American Section of the International Solar Energy Society, Inc. 


\begin{tabular}{|c|c|c|}
\hline $\begin{array}{l}\text { Document Control } \\
\text { Page }\end{array}$ & $\begin{array}{r}\text { 1. SERI Report No. } \\
\text { TR-632-385 }\end{array}$ & 3. Recipient's Accession No: \\
\hline \multirow{2}{*}{\multicolumn{2}{|c|}{$\begin{array}{l}\text { 4. Title and Subtitle } \\
\text { Preliminary Operational Results of the Low-Temperature } \\
\text { Solar Industrial Proçess Heat Field Tests }\end{array}$}} & $\begin{array}{r}\text { 5. Publication Date } \\
\text { June } 1980\end{array}$ \\
\hline & & 6. \\
\hline \multicolumn{2}{|l|}{ 7. Author(s) } & 8. Periorming Organization Rept. No. \\
\hline \multicolumn{2}{|c|}{$\begin{array}{l}\text { 9. Performing Organization Name and Address } \\
\text { Solar Energy Research Institute } \\
\text { 1617 Cole Boulevard } \\
\text { Golden, Colorado } 80401\end{array}$} & $\begin{array}{l}\text { 10. Project/Task/Work Unit No. } \\
3472.00 \\
\begin{array}{l}\text { 11. Contract (C) or Grant (G) No. } \\
\text { (C) } \\
\text { (G) }\end{array}\end{array}$ \\
\hline \multirow{2}{*}{\multicolumn{2}{|c|}{ 12. Sponsoring Organization Name and Address }} & $\begin{array}{l}\text { 13. Type of Report \& Perioa Covered } \\
\text { Technical Beport }\end{array}$ \\
\hline & & 14. \\
\hline \multicolumn{3}{|l|}{ 15. Supplementary Notes } \\
\hline \multicolumn{3}{|c|}{$\begin{array}{l}\text { 16. Abstract (Limit: } 200 \text { words) } \\
\text { Six solar industrial process heat field tests funded by the U.S. Department of } \\
\text { Energy have been in operation for a year or more--three are hot water systems and } \\
\text { three are hot air systems. All are low-temperature projects (process heat at } \\
\text { temperatures below } 212^{\circ} \mathrm{F} \text { ). This report presents performance results gathercd by } \\
\text { each contractor's data acquisition system and summarizes project costs and prob- } \\
\text { lems enrountered. Flat-plate, evacuated-tube, and line-focus collectors are all } \\
\text { represented in the program, with collector array areas ranging from } 2500 \text { tu } \\
21,000 \mathrm{ft} \text {. Collectbr array efficiencies ranged from } 12 \% \text { to } 36 \% \text { with net system } \\
\text { efficiences from } 8 \% \text { to } 33 \% \text {. Low efficiencies are attributable in some cases to } \\
\text { high thermal losses dud, lur the two projccts using air collertors, are due in } \\
\text { part to high parasic1c power cuusumption. Problcme have included industrial } \\
\text { effluents on collectors, glazing and absorber surface failures, excessive thermal } \\
\text { losses, freezing and overheating, control problems, and data acquisition system } \\
\text { failine. With design and data acquisition costs excluded costs of the projects } \\
\text { ranged from } \$ 25 / \mathrm{ft} 2 \text { to } \$ 87 / \mathrm{ft}{ }^{2} \text { and } \$ 499 /(\mathrm{MBtu} / \mathrm{yr} \text { ) to } \$ 1537 /(\mathrm{MBtu} / \mathrm{yr} \text { ). }\end{array}$} \\
\hline \multicolumn{3}{|c|}{$\begin{array}{l}\text { a. Descriptors Industrial Process Heat ; Low 'lemperature; Testiny ; Hot Water ; } \\
\text { Hot Air ; Pertormance; Perfurmance Testing; Data Acquisition Systems } \\
\text { b.ldentifiers/Open-Ended Terms Gampbell Soup Plant, Sacramento, CA; Riegel Textile } \\
\text { Corporation, LaFrance, SC; York Building Products, Incorporated, Harrisburg, YA; } \\
\text { Gold Kist Soybean Plant, Decatur, AL; J. A. LaCour Kiln Services, Incorporated, } \\
\text { c.UC Categories Canton, MS }\end{array}$} \\
\hline \multicolumn{3}{|l|}{$59 b$} \\
\hline \multirow{2}{*}{\multicolumn{2}{|c|}{$\begin{array}{l}\text { 18. Availability Statement } \\
\text { National Technical Information Service } \\
\text { U.S. Department of Commerce } \\
5285 \text { Port Royal Road } \\
\text { Springfield, Virgin1a } 22161\end{array}$}} & 19. No. of Pages \\
\hline & & 20. Price \\
\hline
\end{tabular}

